\title{
INCREASE IN ABUNDANCE AND SPECIES RICHNESS OF FLIES (DIPTERA, BRACHYCERA) IN THE LAKE ENGURE NATURE PARK, LATVIA: EFFECTS OF CLIMATE WARMING?
}

\author{
Viesturs Melecis", Aina Karpa, and Kristaps Vilks \\ Institute of Biology, University of Latvia, Miera iela 3, Salaspils, LV-2169, LATVIA \\ vmelecis@email.lubi.edu.Iv \\ \# Corresponding author
}

Contributed by Viesturs Melecis

\begin{abstract}
The article discusses changes in species richness and numbers of flies (Diptera, Brachycera) in the Lake Engure Nature Park (LENP) during 1995-2012. The study was performed within the framework of the National Long Term Ecological Research (LTER) network of Latvia. During the period of study, a statistically significant increase in positive temperature sums $\left(>4^{\circ} \mathrm{C}\right)$ was observed at the local meteorological station $\left(R^{2}=0.489 ; \mathrm{P}<0.01\right)$. Insects were collected three times per season (June, July, and August) by entomological sweep net from twelve sample plots, which represented a variety of habitats of the LENP - dry xerophytic, mesophytic and humid hygrophytic ones. In total 411 species from 35 families were identified. Dry sample plots showed a statistically significant increase in species richness and/or numbers of flies during the period of study. Humid sample plots did not show any statistically significant trends except for two grassland plots where large herbivores were introduced in 2005 for grassland management purpose. Pooling the data from all sample plots, except those grazed by large herbivores, yielded a statistically significant trend of increase in species richness of flies $\left(R^{2}=0.647 ; \mathrm{P}<0.01\right)$. Among the main trophic groups zoophagous species showed the largest number of statistically significant positive trends mostly within the dry sample plots. For several sample plots significant positive correlations were recorded between species richness of zoophagous flies and annual sums of positive temperatures. It was hypothesised that climate warming may have an indirect effect via interaction with other environmental factors such as moisture regime, nitrogen pollution, and vegetation structure.
\end{abstract}

Key words: LTER network, long-term research, grazing effects on fly species diversity, increase in positive temperature sums.

\section{INTRODUCTION}

Changes in species diversity due to climate warming are among the most urgent ecological problems. Until now the largest amount of evidence clearly indicating effects of climate warming on phenology, distribution, and interspecific relationships has been compiled for well-known, economically significant or protected species (Chapin et al., 2000; Hughes, 2000; McCarry, 2001; Walther et al., 2002; Parmesan and Yohe, 2003; Root et al., 2003; Parmesan, 2006; Walther et al., 2010). Based on existing knowledge on species biology, even mathematical models have been developed to predict species spreading or extinction (Sala et al., 2000; Hill et al., 2002; Chris et al., 2004). However, these predictions are too imprecise because they do not consider interactions between climatic factors and various local anthropogenic factors (Pearson and Dawson, 2003; Stuart, 2008).
Meanwhile there is almost no information regarding the effects of climate warming on small hidden living invertebrates, whose ecological significance due to huge numbers and high reproduction rates should be very high, given their important role in functioning of ecosystems and provision of vital services to human society (Walther et al., 2002). The only option to obtain data on changes in such organisms is the long-term ecological research.

One such invertebrate group is insects as they can be affected by climate change due to their rapid reproduction rates, short development periods and high sensitivity to temperature and humidity (Hövemeyer 2000, Bale et al., 2002; Menendez, 2007). Still there is little information regarding effects of climate warming on them. Similarly to other groups of organisms mainly conspicuous species have been studied such as butterflies, dragonflies, grasshoppers, locusts, and beetles (see reviews of Hickling et al., 2006; 
Menéndez, 2007). The longest time series, more than 30 years, exist on phenology and distribution of British butterflies (Roy and Sparks, 2000; Hill et al., 2002). More detailed long-term data are available also on some agricultural pests such as aphids and biting mosquitoes (Menéndez, 2007).

Flies and other Diptera belong to one of the species richest groups of insects. There are about 30000 species of Diptera currently known from the Palaearctic region (Hövemeyer 2000). About 50-150 species of soil-dwelling Diptera occur commonly in every vegetation formation in one locality in the temperate zone (Frouz, 1999). Diptera belong to the most abundant invertebrates in collections from the grass layer (Melecis et al., 1998). Diptera represent all trophic groups - phytophages, zoophages, and saprophages in most ecosystems. Diptera are richer in species and have a higher biomass than other insects involved in litter decomposition. In the larval stage they play a decisive role in the breakdown of dead organic matter and in nutrient cycling, thereby being central to the functioning of most ecosystems (Hövemeyer, 2000). Their populations are highly dynamic and sensitive to changes in environmental factors. From this point of view, insects, in particular Diptera, are considered to be one of the most promising model groups for long-term studies on the effects of climate change on species diversity (Schowalter, 2000).

The suborder Brachycera joins 120 families of flies, which are mostly 1-3 $\mathrm{mm}$ in length and have reduced antennae. The life cycle of flies combines usually slowly mowing larvae and highly mobile adults (Frouz, 1999). Larvae of many species develop on plants, in soil, crop residues, animal excreta and corpses, some species are zooparasites (Hennig, 1973; Schowalter, 2000). Adult flies as flying insects can quickly colonize new habitats that have become suitable for the development of larvae due to possible changes of climatic or other environmental factors (Frouz, 1999). Flight activity of adult flies depends on sufficiently high temperatures (Hövemeyer, 2000).

Biological processes are largely determined by the sums of positive temperatures (Holdridge, 1967). Duration of development of insect eggs and larvae, gonadal maturation processes and other physiological processes are largely determined by duration of exposure and range of temperature (Schowalter, 2000). Southern species in the northern regions are unable to undergo full life cycle just due to a short vegetation season and low summer temperatures; thus, the prolongation of the vegetation season could be an important factor in the expansion of the species in northern areas (Menéndez, 2007). Characterization of the effects of climate change on these organisms by using positive temperature sums seems to be more important than changes in mean temperatures.

Climate warming in Latvia has been clearly documented by analyzing the average annual temperature changes over the past decades (Lizuma, 2000; Kḷaviņš et al., 2002).
In Latvia so far the only published long-term study on the effects of climate change on species diversity refers to avifauna (Vīksne, 2000) and soil Collembola (Juceviča and Melecis, 2002; 2006).

In 1995, a national project financed by Latvian Council of Sciences was launched in the Lake Engure Nature Park (LENP) (Melecis, 2000). Twelve sample plots were selected within the Park for long-term studies of plant communities and grass dwelling invertebrates (Karpa, 2000). In 2004, Latvia was admitted to the International Long-Term Ecological Research (ILTER) network (http://www.ilternet.edu) and the sample plots were included in the Engure LTER site which is one of the sites of the Latvian National LTER network (Melecis et al., 2005).

The aim of this paper is to perform preliminary analysis of long-term changes in species richness and numbers of flies (Diptera, Brachycera) collected from 12 LTER sample plots of the Engure LTER site on the background of climate changes characterised by annual precipitation and trends in positive temperature $\left(>+4{ }^{\circ} \mathrm{C}\right)$ sums.

\section{MATERIALS AND METHODS}

Study site. The twelve LTER sample plots within the Engure LTER site represent widespread as well as some rare habitats of the LENP (Fig. 1; Table 1). Selection of sample plots was made from habitat distribution maps of the LENP (Anonymous, 2010a). The number and location of sample plots was planned with the aim to perform sampling of insects during a one-day field trip in short time intervals. The size of a sample plot varied between $2000-2500 \mathrm{~m}^{2}$ depending on homogeneity of habitat vegetation and relief.

The assignment of sample plot vegetation to classes and the alliances by phytosociological classification was based on previous studies (Gavrilova et al., 2011). Names of syntaxa follow the classification scheme of European vegetation by Rodwell et al. (2003). Assignment of monitoring sites to Natura 2000 habitat types defined by the European Council Directive 92/43/EEC of 21 May 1992 on the conservation of natural habitats and of wild fauna and flora was done using Interpretation manual of European Union Habitats (Anonymous, 2007) and interpretation manual of EU habitats in Latvia (Auniņš, 2010).

More detailed description of vegetation and analysis of long-term changes of plant communities can be found in Rūsina et al. (2014). These data were used to help interpret changes observed in species richness of flies of the studied sample plots.

All the selected sample plots were divided into two groups according to the results of DCA ordination of vegetation data (Rūsiņa et al., 2014):

- Dry or moderately wet habitats on sandy soils, with xerophytic or mesophytic vegetation (S1, S4, S5, S11, S12); 


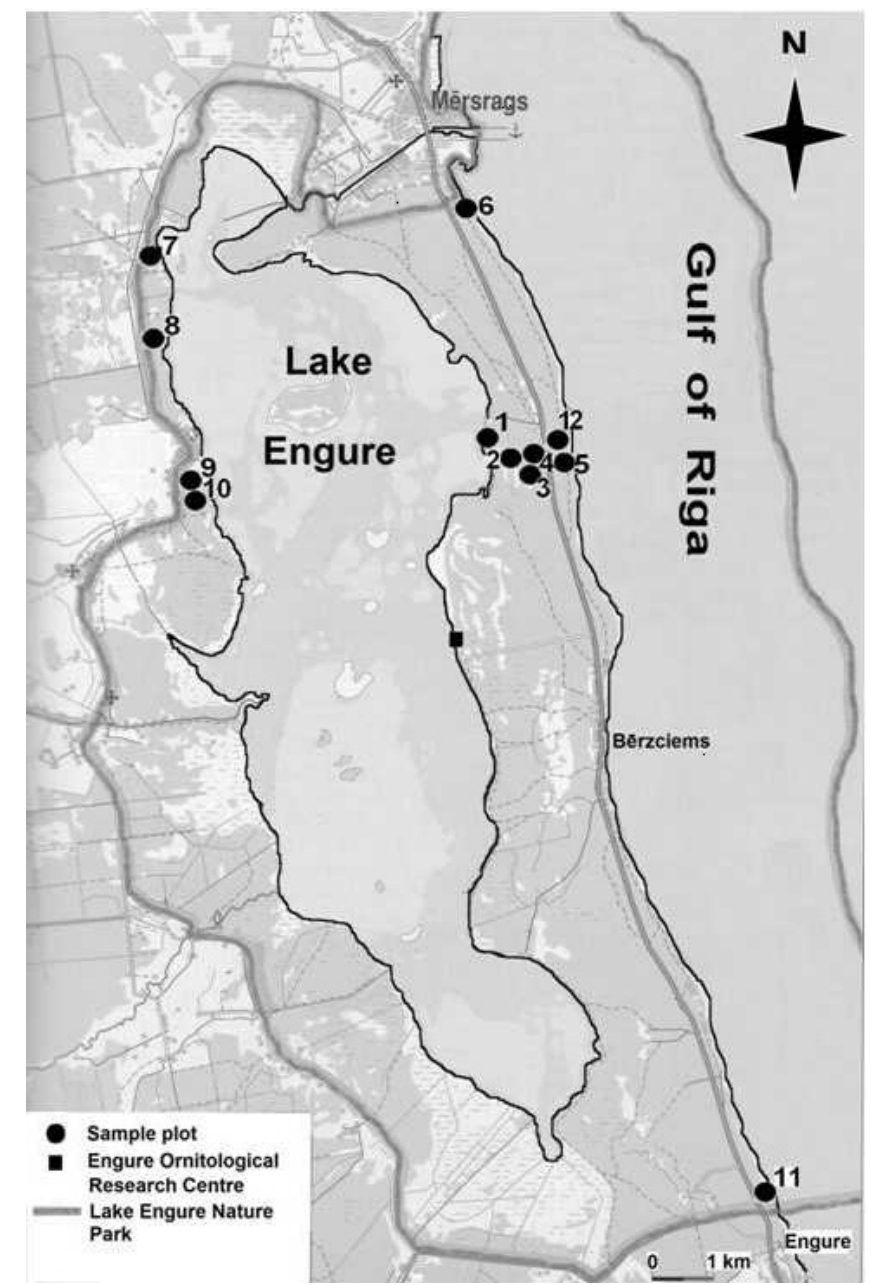

Fig. 1. Location of Long-Term Ecological Research sample plots in the Lake Engure Nature Park. 1 - Grassland alongside Lake (S1); 2 - Humid calcareous dune slack (S2); 3 - Humid pine forest in shallow dune slack (S3); 4 - Dry pine forest (S4); 5 - White dune on the beach (S5); 6 - Humid coastal grassland (S6); 7 - Humid deciduous forest on mineral soil (S7); 8 - Flood-plain calcareous fen (S8); 9 - Humid calcareous grassland (S9); 10 - Poor fen (S10); 11 - Dry pine forest on gray dune (S11); 12 Mesic pine forest (S12).

- Humid habitats with hygrophytic vegetation (S2, S3, S6, S7, S8, S9, S10).

Collection and identification of flies. Insects were collected from the grass floor three times per vegetation season - late June, mid-July and early August. The entomological sweep-net method was used (Karpa, 2000). One sample consisted of 100 strokes made by a collector while he was moving along a $50 \mathrm{~m}$ long route crossing the sample plot. Arthropods were collected in a small nylon gauze bag attached to a metal ring fastened at the bottom edge of the entomological net. The bag was removed after sweeping, tied, labelled, and placed in a plastic bag with ethyl-acetate vapour (killing agent for arthropods). In the laboratory the arthropods were sorted and counted. Flies were mounted on entomological pins or storied in ethyl-acetate vapour until species identification. Collection of insects was performed on days with warm sunny weather in the afternoon after the dew had dried from vegetation.
Collection of insects within the sample plot S12 representing mesic pine forest was started two years later, in 1997. The data from humid deciduous forest S7 were missing in 1997 for technical reasons. In 2005, using large herbivores (wild cows and wild Konik horses) was introduced to the humid calcareous grassland S9 and poor fen S10. The presence of high numbers of animals, grazing, trampling and manuring the site might have affected insect communities of these sample plots.

Identification of flies was performed mainly according to keys of Bei-Bienko (Бей-Биенко, 1969; 1970). Families Lauxaniidae species were identified by using keys of Remm and Elberg, 1979. Species of the family Drosophilidae were identified using unpublished keys prepared by Swedish entomologist S. A. Escher. Species of the family Dolichopodidae were identified by using keys of Grichanov (2006), Meuffels and Grootaert (1990), Bei-Bienko (Бей-Биенко, 1969) and Pollet (1990, 1996). Representatives of several families such as Muscidae, Phoridae, Lonchopteridae, Lonchaeidae, Agromyzidae, Sphaeroceridae, and Antomyiidae, are still under processing.

Meteorological data. Meteorological data were obtained from Mērsrags meteorological station located in the Northern part of the region. Annual precipitation and sums of positive temperatures were calculated by cumulative average decade temperatures $\left(>+4{ }^{\circ} \mathrm{C}\right)$ of the year.

Data analysis. Linear regression was used for trend analysis in annual meteorological data, abundance, and species richness of flies. When performing trend analysis the seasonal data for each sample plot were pooled to eliminate random effects and intra-seasonal fluctuations of meteorological factors. Calculations were performed separately for each sample plot as well as for pooled data from combined sample plots to obtain an insight in landscape level changes of abundance and species richness of flies. As collection of insects in the sample plot S12 was started two years later (1997-2012), a comparison was made between trend lines in species richness calculated separately for pooled data from S1, S2, S3, S4, S5, S6, S7, S8, S11, and S12 (for the period 1997-2012), and for pooled data from S1, S2, S3, S4, S5, S6, S7, S8, and S11 (for the period 1995-2012). The data from S9 and S10 were omitted because fly communities of these plots were strongly affected by introduction of wild herbivores.

Two groups of sample plots representing dry and humid habitats were compared with respect to trends in abundance and species richness of flies.

Similar analysis, except for pooled data, was performed on the major trophic groups of flies — phytophagous, zoophgous, and saprophagous species. Information on species biology was taken from identification keys (Бей-Биенко 1969; 1970; Remm and Elberg, 1979).

Pearson correlation coefficients were calculated for each sample plot between variables describing total abundance 
CHARACTERISTICS OF LONG-TERM RESEARCH SAMPLE PLOTS OF THE LAKE ENGURE NATURE PARK

\begin{tabular}{|c|c|c|c|}
\hline $\begin{array}{c}\text { Sample plot name } \\
\text { (designation) }\end{array}$ & $\begin{array}{l}\text { Geographical } \\
\text { coordinates* }\end{array}$ & Plant community characteristics & Remarks \\
\hline $\begin{array}{l}\text { Grassland alongside } \\
\text { Lake Engure } \\
\text { (S1) }\end{array}$ & $\begin{array}{l}\text { N } 57^{\circ} 17^{\prime} 17.7^{\prime \prime} \\
\text { E } 23^{\circ} 08^{\prime} 30.3^{\prime \prime}\end{array}$ & $\begin{array}{l}\text { Cl. Koelerio-Corynephoretea** } \\
\text { All. Plantagini-Festucion*** } \\
\text { Frequent species: Deschampsia flexuosa, Melampyrum } \\
\text { pratense, Luzula pilosa, Trientalis europaea, } \\
\text { Anthoxanthum odoratum, Carex arenaria, Agrostis tenuis }\end{array}$ & $\begin{array}{l}\text { Dry, sandy soils, grassland with sparsely standing trees } \\
\text { Pinus sylvestris. Not widely distributed habitat type in } \\
\text { LENP. } \\
\text { Do not correspond to any Natura } 2000 \text { habitat type. }\end{array}$ \\
\hline
\end{tabular}

\begin{tabular}{|c|c|}
\hline Humid calcareous & N $57^{\circ} 17^{\prime} 13.9^{\prime \prime}$ \\
\hline $\begin{array}{l}\text { dune slack } \\
\text { (S2) }\end{array}$ & E $23^{\circ} 08^{\prime} 57.8^{\prime \prime}$ \\
\hline
\end{tabular}

Humid pine forest in N $57^{\circ} 17^{\prime} 1.8^{\prime \prime}$ shallow dune slack E $23^{\circ} 09^{\prime} 01.9^{\prime \prime}$ (S3)

$\begin{array}{ll}\begin{array}{l}\text { Dry pine forest } \\ \text { (S4) }\end{array} & \text { N } 57^{\circ} 17^{\prime} 20.4^{\prime \prime} \\ & \text { E } 23^{\circ} 09^{\prime} 13.2^{\prime \prime}\end{array}$

White dune on the $\mathrm{N} 57^{\circ} 17^{\prime} 19.3^{\prime \prime}$
$\begin{aligned} & \text { beach } \\ & \text { (S5) } 23^{\circ} 09^{\prime} 51.3^{\prime \prime}\end{aligned}$

Humid coastal grass- N 57 $17^{\prime} 28.8^{\prime \prime}$ land E $23^{\circ} 08^{\prime} 04.7^{\prime \prime}$ (S6)

$\begin{array}{ll}\text { Humid deciduous } & \text { N } 57^{\circ} 18^{\prime} 08.0^{\prime \prime} \\ \text { forest on mineral } & \text { E } 23^{\circ} 02^{\prime} 56.5^{\prime \prime} \\ \text { soil } & \\ \text { (S7) } & \end{array}$

Flood-plain calcare- N 57 $18^{\prime} 08.5^{\prime \prime}$ ous fen E $23^{\circ} 03^{\prime} 14.5^{\prime \prime}$ (S8)

\begin{tabular}{|c|c|}
\hline Humid calcareous & N $57^{\circ} 17^{\prime} 03.8^{\prime \prime}$ \\
\hline grassland & E $23^{\circ} 03^{\prime} 52.8^{\prime \prime}$ \\
\hline
\end{tabular}
(S9)

$\begin{array}{ll}\text { Poor fen } & \text { N } 57^{\circ} 17^{\prime} 02.7^{\prime \prime} \\ \text { (S10) } & \text { E } 23^{\circ} 03^{\prime} 54.6^{\prime \prime}\end{array}$
$\begin{array}{ll}\text { Dry pine forest on } & \text { N } 57^{\circ} 10^{\prime} 41.4^{\prime \prime} \\ \text { gray dune } & \text { E } 23^{\circ} 13^{\prime} 16.5^{\prime \prime}\end{array}$ (S11)

Mesic pine forest $\quad$ N 57 $17^{\prime} 23.0^{\prime \prime}$ (S12) E $23^{\circ} 09^{\prime} 41.3^{\prime \prime}$

\section{Cl. Scheuchzerio-Caricetea fuscae}

All. Caricion davallianae

Frequent species: Schoenus ferrugineus, Phragmites australis, Primula farinosa, Epipactis palustris

\section{Cl. Vaccinio-Piceetea}

All. Seslerio-Pineetum

Frequent species: Pinus sylvestris, Myrica gale, Molinia caerulea, Equisetum variegatum, Vaccinium myrtillus $V$. vitis-idea, Carex nigra

\section{Cl. Vaccinio-Piceetea}

All. Dicrano-Pinion

Frequent species: Pinus sylvestris, Carex arenaria, Deschampsia flexuosa, Carex arenaria, Melampyrum pratense

\section{Cl. Ammophiletea}

\section{All. Ammophilion}

Frequent species: Elymus arenarius, Elytrigia repens,

Leymus arenarius, Honckenya peploides

Cl. Molinio-Arrhenatheretea All. Calthion

Frequent species:

Anthoxanthum odoratum, Carex nigra, Angelica sylvestris, real Baltic coastal meadows

Ranunculus acris, Hydrocotyle vulgaris, Trifolium

pratense, Potentilla anserine

\section{Cl.Vaccinio-Piceetea}

\section{All. Seslerio-Pineetum}

Frequent species: Schoenus ferrugineus, Menyanthes trifoliata, Phragmites australis,

Molinia caerulea, Filipendula ulmaria, Geum rivale, Pyrola rotundifolia

\section{Cl. Scheuchzerio-Caricetea fuscae}

All. Caricion davallianae

Frequent species Phragmites australis, Schoenus

ferrugineus, Cladium mariscus, Myrica gale, Menyanthes trifoliata

\section{Cl. Molinio-Arrhenatheretea, All. Molinion}

Frequent species: Sesleria caerulea, Carex nigra, $C$. panicea, C. flaca, Thalictrum simplex, Potentilla erecta, Peucedanum palustre;

Cl. Scheuchzerio-Caricetea fuscae

All. Caricion fuscae

Frequent species: Carex nigra, Comarum palustre,

Naumburgia thyrsiflora, Calamagrostis neglecta

\section{Cl. Vaccinio-Piceetea}

All. Dicrano-Pinion

Frequent species: Pinus sylvestris, Geranium sanguineum, dunes.
Festuca ovina, Vaccinium vitis-idaea, V. myrtillus, Orthilia secunda, Fragaria vesca

\section{Cl. Vaccinio-Piceetea}

All. Dicrano-Pinion

Frequent species:

Pinus sylvestris, Empetrum nigrum, Vaccinium myrtillus,

V. vitis-idaea, Melampyrum pratense, Calluna vulgaris
Almost permanently humid, widely distributed habitat type in LENP. Natura 2000 habitat type 2190 Humid dune slacks.

Pine forest on humid sandy solis with Myrica gale in undergrowth, rare habitat type in LENP. Natura 2000 habitat type 2190 Humid dune slacks.

Pine forest with sparse herb cover on dry sandy soils. Widely distributed habitat type in LENP. Natura 2000 habitat type 2180 Wooded dunes.

White dune overgrowing with perrennial herbs on dry sandy soils. Common habitat on the sea coast. Natura 2000 habitat type 2120 Shifting dunes along the shoreline with Ammophila arenaria (white dunes).

Habitat subjected to the impact of the sea, not very widely distributed in LENP. Natura 2000 habitat type 1630* Bo-

Humid deciduous forest on sandy soils with Alnus glutinosa, Rhamnus catharcticus, Betula pendula. Widely distributed habitat type in LENP. Natura 2000 habitat type 2190 Humid dune slacks.

Flood-plain fen on mineral soils. Widely distributed habitat type in LENP. Natura 2000 habitat type 7230 Alkaline fens.

Humid grassland. Widely distributed habitat type in LENP. Natura 2000 habitat type 6410 Molinia meadows on calcareous, peaty or clayey-silt-laden soils. Introduction of wild herbivores in 2005 , subsequently heavily grazed.

Humid grassland. Quite common habitat type in LENP. Do not correspond to any Natura 2000 habitat type. Introduction of wild herbivores in 2005, subsequently heavily grazed.

Dry pine forest on grey dune. Very widely distributed habitat type in LENP. Natura 2000 habitat type 2180 Wooded

Pine forest on sandy mineral soil with well developed organic horizon. Very widely distributed habitat type in LENP. Natura 2000 habitat type 2180 Wooded dunes.

\footnotetext{
* Coordinates of the initial point of the insect sampling transect

$* *$ Cl. - class of phytosociological classification (Rodwell et al., 2003)

*** All. - alliance of phytosociological classification (Rodwell et al., 2003)
} 
and species richness, abundance and species richness of separate trophic groups, annual precipitation and positive temperature sums. Considering deviations from the normal distribution in our data and problems of testing significance of elements of large correlation matrices (Gotelli and Ellison, 2004) we chose bootstrapping by case resampling algorithm for assessment of $95 \%$ confidence intervals for Pearson correlation coefficients (Davison and Hinkley, 1997). Calculations were performed using the programme package SPSSInc PASWStatistics 18.

\section{RESULTS}

Changes in temperature and precipitation at the Mērsrags meteorological station

In 1995-2012, a statistically significant increase in positive $\left(+4{ }^{\circ} \mathrm{C}\right)$ temperature sums was recorded, while the precipitation varied considerably over the years (Fig. 2).

General characteristics of collected material. 411 species of flies from 35 families were identified in the collected material. Sample plots differed considerably both in abundance and species richness (Annex). The highest numbers of individuals (3304) was found in the humid coastal grassland (S6), and the least numbers (514) was collected in the dry pine forest (S4). The highest species richness - 175 was found in plot S6, and the lowest (57 species) in plot S4. Only nine species Haematopota pluvialis, Bicellaria vana, Hybos culiciformis, Chamaemyia polystigma, Trachysi-
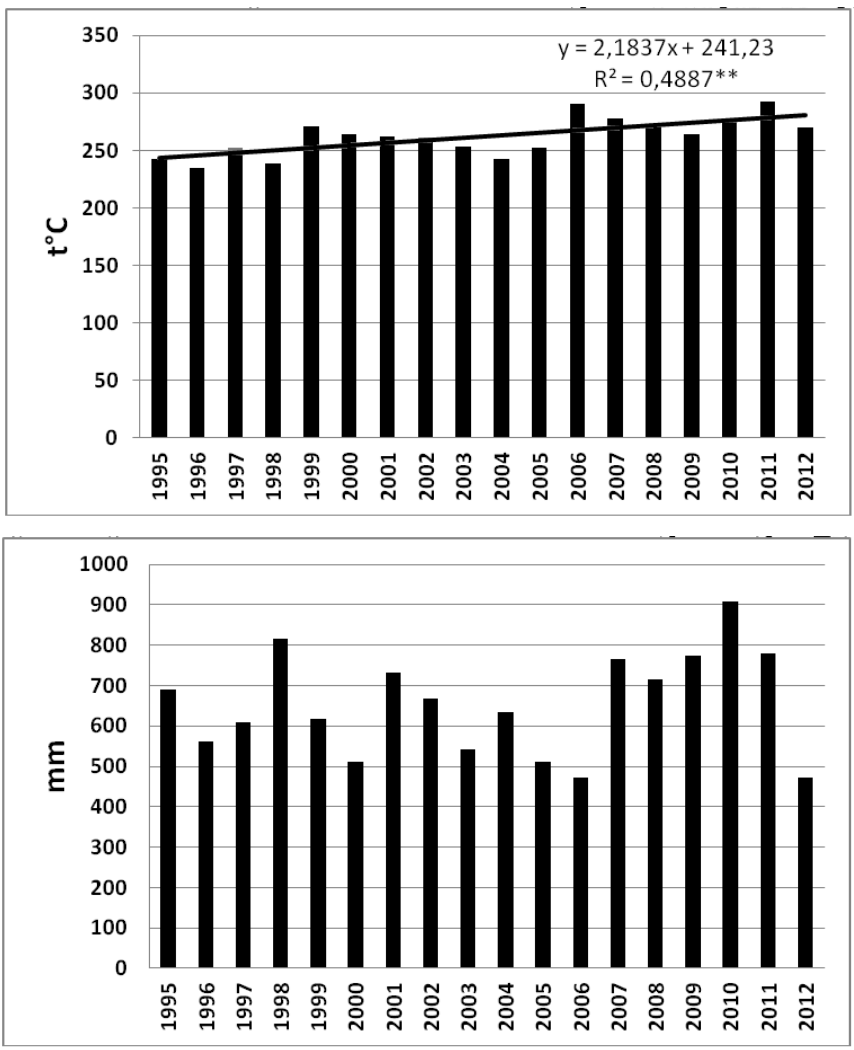

Fig. 2. Changes in positive temperature $\left(>+4{ }^{\circ} \mathrm{C}\right)$ sums and precipitation $(\mathrm{mm})$ during the period of 1995-2010 at the Mērsrags meteorological station. Asterisks show the significance level of linear trend: $* * P<0.01$. phonella pygmaea, Sepsis cynipsea, Sepsis fulgens, Anthomyza collini, Anthomyza gracilis were present in all sample plots, and 136 only in one sample plot (Annex). Five species Chamaemyia flavipalpis, Parydra unicolor, Parallelomma albipes, Colobaea distincta, Euthycera fumigate, were new to the fauna of Latvia. However, none of the species can be considered as a southern element in Latvian fauna.

Changes in total abundance and species richness. All of the dry xero- and mesophytic sample plots (S1, S4, S5, S11, and S12) showed a statistically significant increase in total numbers and/or species richness of flies during the study period, except for S1 with a non-significant trend (Fig. 3). For the humid hygrophytic sample plots (S2, S3, S6, S7, and S8) no clear trends were observed except for S9, and $\mathrm{S} 10$ where increase in numbers of flies and species richness was recorded after introduction of wild herbivores in 2005 (Fig. 4).

Changes in species richness of various trophic groups in dry sample plots. All of the dry xero- and mesophytic sample plots showed a statistically significant increase in zoophagous species richness and/or abundance during the period of study. These sample plots included a white dune (S5), dry pine forest on gray dune (S11), dry pine forest (S4), and mesic pine forest (S12) (Table 2). In the white dune plot species richness significantly increased in all trophic groups (Table 2). Phytophagous flies significantly increased only in the white dune (S5) and dry pine forest (S4), and saprophagous flies in white dune (S5) and mesic pine forest (S12) (Table 2).

Changes in species richness of various trophic groups in humid sample plots

Only two humid hygrophytic sample plots - humid coastal grassland (S6) and humid deciduous forest (S7) showed a statistically significant increase in species richness and/or abundance of zoophagous flies (Table 2). Species richness of saprophagous flies statistically increased significantly only in the humid calcareous dune slack (S2) (Table 2).

Effects of introduction of large herbivores on species richness of major trophic groups. Introduction of large herbivores (wild cows and Konik horses) to the LENP humid calcareous grasslands (S9) and poor fen (S10) in 2005 resulted in a sharp increase in species richness for all of the major trophic groups (Table 2). However, the most pronounced increase (the highest values of $\mathrm{R}^{2}-0.656$ for $\mathrm{S} 9$ and 0.636 for S10) was observed in saprophagous flies.

Changes in species richness of flies in pooled data. Analysis of pooled data resulted in a statistically significant positive increase from 70-100 species of flies in the first years 1995-2000 of investigation up to 120-160 species in 2001-2012 (Fig. 5). The lack of data for 2007 for the site S7 did not much affect the result. The tested regression lines were similar when the data from sample plot S12 were added or removed. 
Grassland alongside Lake Engure (S1)
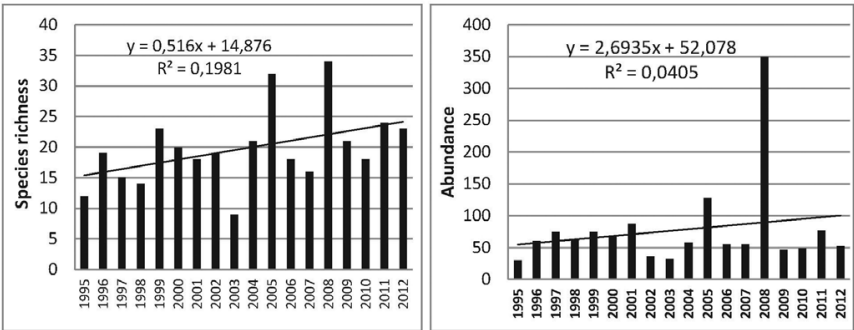

Dry pine forest (S4)
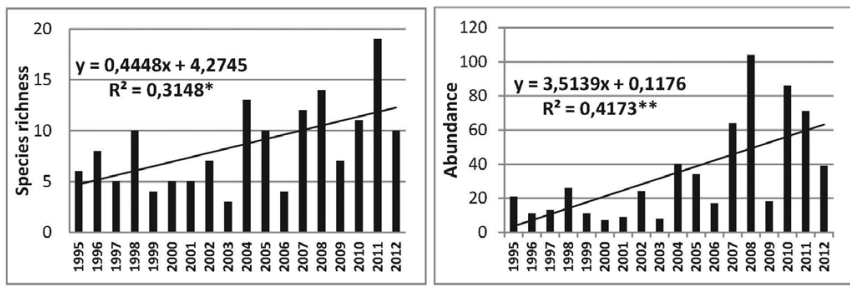

White dune on the beach (S5)
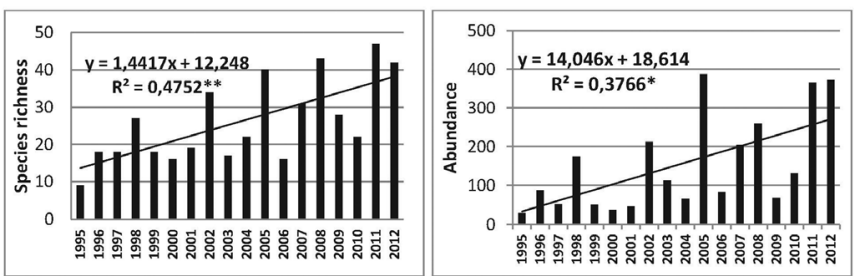

Dry pine forest on gray dune (S11)
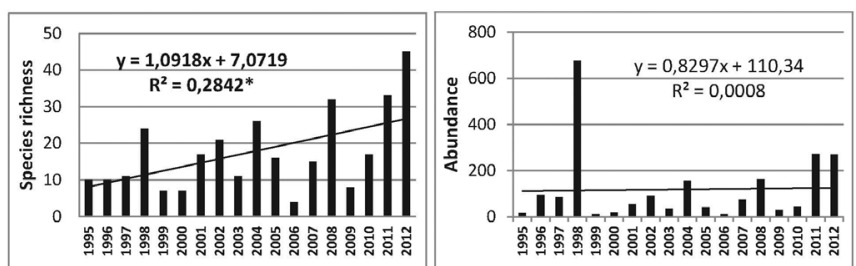

Mesic pine forest (S12)
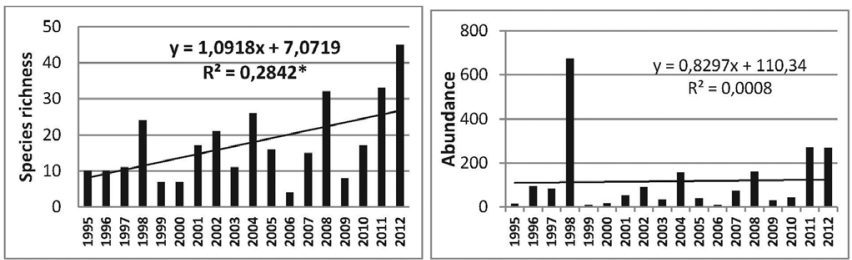

Fig. 3. Long-term changes in species richness and abundance of Diptera Brachycera in dry xerophytic and mesophytic sample plots of the Lake Engure Nature Park. Asterisks show the significance level of linear trend: $* P<0.05, * * P<0.01$.

Correlations with meteorological data. Statistically significant correlations of positive temperature sums with total species richness and abundance were found only for sample plots S3, S9, S10, and S12 (Table 3). Zoophagous diptera showed the highest number of significant correlations with positive temperature sums (sample plots S1, S3, S4, S7, and S9). Phytophagous and saprophagous diptera had significant correlations with temperature data only for sample plots S9 and S10. Of the sample plots mentioned above S1, $\mathrm{S} 4$, and $\mathrm{S} 12$ represented dry habitats, and $\mathrm{S} 3, \mathrm{~S} 7, \mathrm{~S} 9$, and S10 humid habitats.
Humid calcareous dune slack (S2)
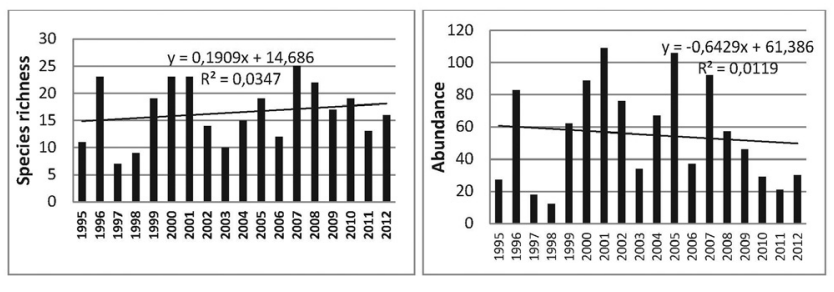

Humid pine forest in shallow dune slack (S3)

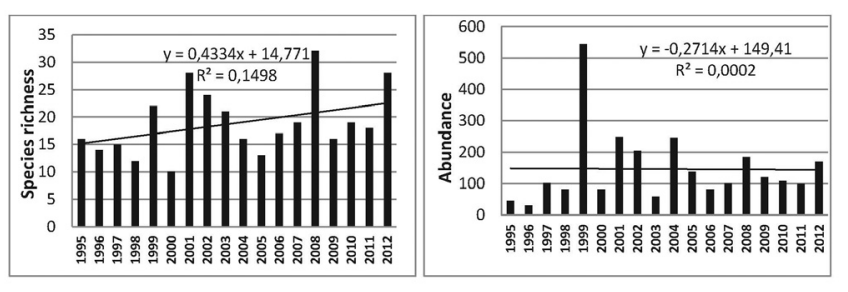

Humid coastal grassland (S6)

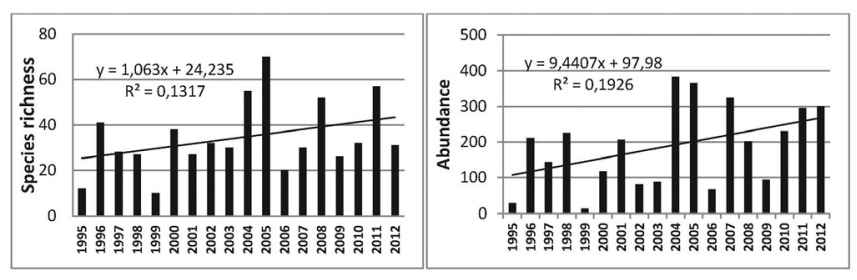

Humid deciduous forest on mineral soil (S7)

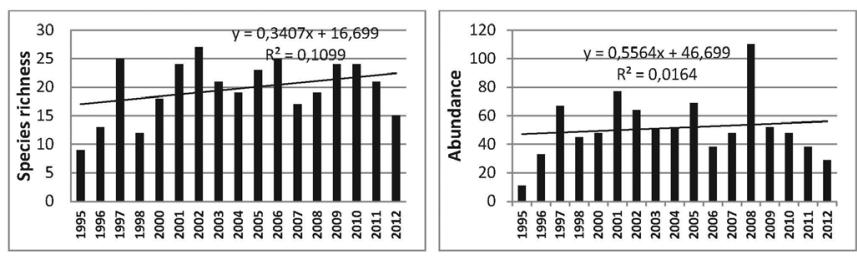

Flood-plain calcareous fen (S8)

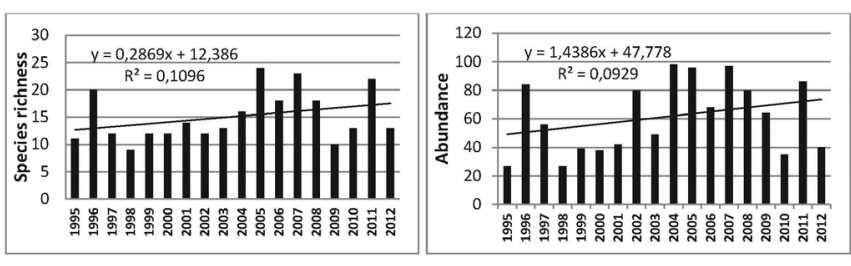

Humid calcareous grassland (S9)

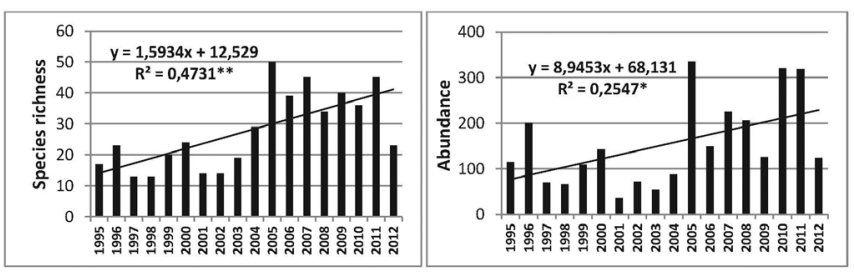

Poor fen (S10)

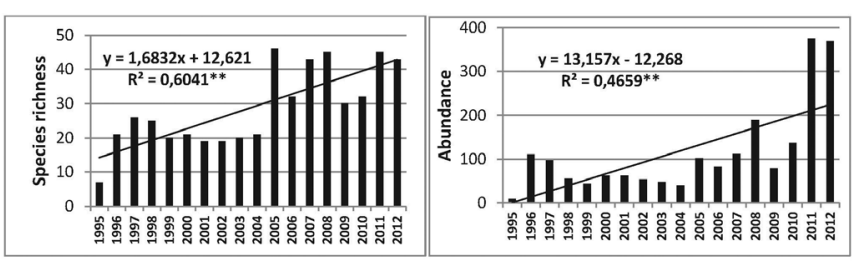

Fig. 4. Long-term changes in species richness and abundance of Diptera Brachycera in humid hygrophytic sample plots of the Lake Engure Nature Park. Asterisks show the significance level of linear trend: ${ }^{*} P<0.05$, ** $P<0.01$. 
Table 2

TREND ANALYSIS OF CHANGES IN SPECIES RICHNESS AND ABUNDANCE OF ZOOPHAGOUS, PHYTOPHAGOUS, AND SAPROPHAGOUS DIPTERA BRACHYCERA IN DRY AND HUMID SAMPLE PLOTS OF THE LAKE ENGURE NATURE PARK

\begin{tabular}{|c|c|c|c|c|c|c|}
\hline \multirow[t]{2}{*}{ Sample plot } & \multicolumn{2}{|c|}{$\begin{array}{c}\text { Zoophagous } \\
\text { Diptera }\end{array}$} & \multicolumn{2}{|c|}{$\begin{array}{c}\text { Phytophagous } \\
\text { Diptera }\end{array}$} & \multicolumn{2}{|c|}{$\begin{array}{c}\text { Saprophagous } \\
\text { Diptera }\end{array}$} \\
\hline & \begin{tabular}{|} 
species \\
richness
\end{tabular} & $\begin{array}{l}\text { abun- } \\
\text { dance }\end{array}$ & \begin{tabular}{|c} 
species \\
richness
\end{tabular} & $\begin{array}{l}\text { abun- } \\
\text { dance }\end{array}$ & \begin{tabular}{|c} 
species \\
richness
\end{tabular} & $\begin{array}{l}\text { abun- } \\
\text { dance }\end{array}$ \\
\hline \multicolumn{7}{|c|}{ Dry sample plots } \\
\hline $\begin{array}{l}\text { Grassland along- } \\
\text { side Lake Engure } \\
\text { (S1) }\end{array}$ & 0.167 & 0.08 & 0.046 & $6 \mathrm{E}-05$ & 0.128 & 0.025 \\
\hline $\begin{array}{l}\text { Dry pine forest } \\
\text { (S4) }\end{array}$ & $0.452 * *$ & $0.320^{*}$ & $0.226^{*}$ & 0.184 & 0.022 & 0.041 \\
\hline $\begin{array}{l}\text { White dune on } \\
\text { the beach (S5) }\end{array}$ & $0.314^{*}$ & $0.310 *$ & $0.483 * *$ & $0.376^{* *}$ & $0.407 * *$ & $0.357^{* *}$ \\
\hline $\begin{array}{l}\text { Dry pine forest } \\
\text { on grey dune } \\
\text { (S11) }\end{array}$ & $0.393 * *$ & 0.109 & 0.101 & 0.018 & 0.178 & 0.0005 \\
\hline $\begin{array}{l}\text { Mesic pine forest } \\
(\mathrm{S} 12)\end{array}$ & $393 * *$ & 0.109 & 0.010 & 0.0004 & $0.320 *$ & 0.034 \\
\hline \multicolumn{7}{|c|}{ Humid sample plots } \\
\hline $\begin{array}{l}\text { Humid calcare- } \\
\text { ous dune slack } \\
\text { (S2) }\end{array}$ & 0.015 & 0.025 & 0.004 & $3 \mathrm{E}-05$ & $0.219 *$ & 0.092 \\
\hline $\begin{array}{l}\text { Humid pine for- } \\
\text { est in shallow } \\
\text { dune slack (S3) }\end{array}$ & 0.138 & 0.006 & 0.090 & 0.030 & 0.054 & 0.031 \\
\hline $\begin{array}{l}\text { Humid coastal } \\
\text { grassland (S6) }\end{array}$ & $0.221^{*}$ & $0.389 * *$ & 0.085 & 0.001 & 0.103 & 0.184 \\
\hline $\begin{array}{l}\text { Humid deciduous } \\
\text { forest on mineral } \\
\text { soil (S7) }\end{array}$ & $0.283^{*}$ & 0.171 & 0.038 & 0.061 & 0.036 & 0.024 \\
\hline $\begin{array}{l}\text { Flood-plain cal- } \\
\text { careous fen (S8) }\end{array}$ & 0.082 & 0.153 & 0.005 & 0.187 & 0.046 & 0.102 \\
\hline $\begin{array}{l}\text { Humid calcare- } \\
\text { ous grassland } \\
\text { (S9) }\end{array}$ & $0.298 *$ & 0.037 & $0.475 * *$ & $0.474 * *$ & $0.657 * *$ & 0.188 \\
\hline Poor fen (S10) & $0.251 *$ & 0.143 & $0.574 * *$ & $0.333^{*}$ & $0.636 * *$ & $0.525 * *$ \\
\hline
\end{tabular}

All trends were positive, because table contains only R-squared values. Asterisks show significance level of linear trend: * $P<0.05$, ** $P<0.01$.

No significant correlations were found between s pecies richness and annual precipitation data. Only total abundance data of humid pine forest in the shallow dune slack (S4) and abundance of saprophagous diptera from the grassland alongside Lake (S1) were positively correlated with precipitation data.

No significant correlations were found between pooled species richness data and meteorological data.

\section{DISCUSSION}

In the material collected during our long-term studies within 12 sample plots of the Lake Engure Nature Park 411 species from 35 families of Diptera Brachycera were identified. Our studies were performed by use of entomological

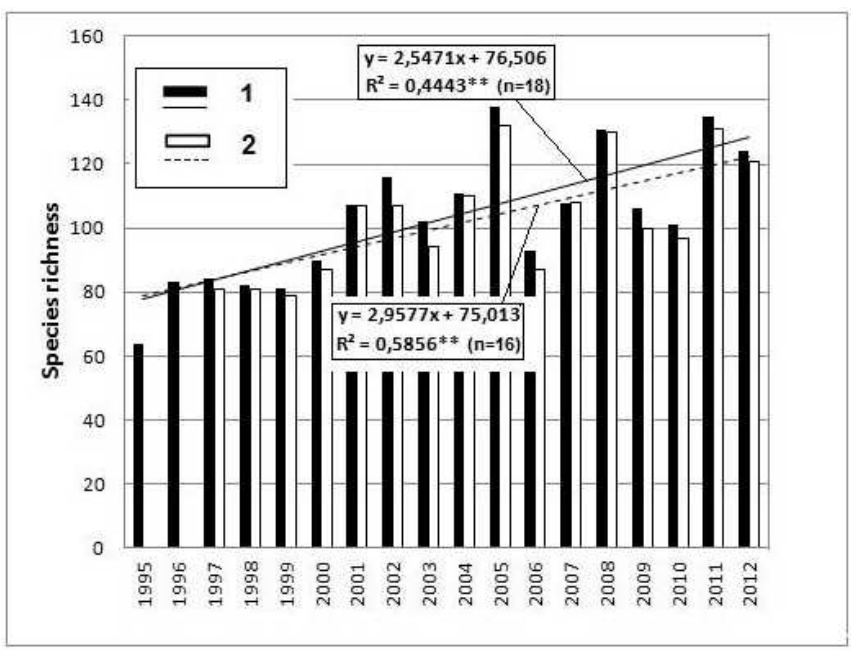

Fig. 5. Long-term changes in total species richness of Diptera Brachycera in sample plots of the Lake Engure Nature Park. 1 - trend line calculated from pooled data of sample plots S1, S2, S3, S4, S5, S6, S7, S8, S11, and $\mathrm{S} 12 ; 2$ - trend line calculated from pooled data of sample plots $\mathrm{S} 1, \mathrm{~S} 2, \mathrm{~S} 3$, S4, S5, S6, S7, S8, and S11. Asterisks show the significance level of linear trend: * $P<0.05, * * P<0.01$.

sweep-net method which has been criticised by some authors (Cothran and Summers, 1972; Hövemeyer, 1999). Hövemeyer (1999) conducted studies of Diptera in Germany in five different habitats, by use of emergency traps. In the collected material 64 families of Diptera were selected for identification yielding 650 species, in total. Despite of the differences in habitats, time intervals and methods used, mean number of species per family in both studies was quite similar (12 in our study, 10 in the German study). Entomological sweep-net method has been successfully used in several studies in Latvia (Melecis et al., 1998; 1999; 2000) and provided comparable results. Of course, some species inhabiting lower layers of grass vegetation evidently were lost during sweeping. The sweep-net method does not rule out also the problem of "tourist species" (Southwood, 1996). However, shortcomings of this method are compensated by its simplicity. It ensures that a large number of habitats can be covered in a short time. Since our study was not focused on precise description of habitat species composition like that of Hövemeyer's, but mostly on investigation of long-term trends in species richness, the problem of "tourist species" was not so important.

Significant trends in annual positive temperature sums during the period of our study are clearly indicative of climate warming while no trends were observed in fluctuations of annual precipitation. Significant positive trends were found also in long-term changes of fly abundance and/or species richness in different sample plots of the LENP. Moreover, the increase in species richness of flies should be considered as a dominant process in the selected habitats, because it was reflected by a positive trend in the pooled data from sample plots.

All sample plots were subdivided in two groups according to DCA of vegetation data (Rūsiña et al., 2014): dry xerophytic, mesophytic and humid hygrophytic habitats. Strik- 
CORRELATIONS OF FLY SPECIES RICHNESS AND ABUNDANCE WITH ANNUAL PRECIPITATION AND POSITIVE TEMPERATURE $\left(>4^{\circ} \mathrm{C}\right)$ SUMS FOR VARIOUS SAMPLE PLOTS OF THE LAKE ENGURE NATURE PARK

\begin{tabular}{|c|c|c|c|c|c|c|c|c|}
\hline \multirow{3}{*}{ Variable } & \multirow{3}{*}{$\begin{array}{c}\text { Sample } \\
\text { plot }\end{array}$} & \multicolumn{3}{|c|}{ Precipitation } & \multicolumn{3}{|c|}{ Positive temperature sums } & \multirow{3}{*}{$\mathrm{n}$} \\
\hline & & \multirow[t]{2}{*}{$\mathrm{R}$} & \multicolumn{2}{|c|}{$95 \%$ confidence interval } & \multirow[t]{2}{*}{$\mathrm{R}$} & \multicolumn{2}{|c|}{$95 \%$ confidence interval } & \\
\hline & & & lower & upper & & lower & upper & \\
\hline Zoophagous species richness & S1 & -0.105 & -0.522 & 0.315 & 0.420 & 0.056 & 0.702 & 18 \\
\hline Zoophagous species richness & S3 & 0.162 & -0.164 & 0.497 & 0.449 & 0.089 & 0.702 & 18 \\
\hline Total species richness & S3 & 0.069 & -0.385 & 0.497 & 0.310 & 0.012 & 0.612 & 18 \\
\hline Zoophagous species richness & S4 & 0.287 & -0.269 & 0.847 & 0.535 & 0.040 & 0.827 & 18 \\
\hline Zoophagous species richness & S7 & -0.050 & -0.515 & 0.502 & 0.623 & 0.228 & 0.804 & 17 \\
\hline Zoophagous species richness & S9 & -0.138 & -0.554 & 0.424 & 0.486 & 0.087 & 0.842 & 18 \\
\hline Phytophagous species richness & S9 & 0.131 & -0.386 & 0.562 & 0.473 & 0.102 & 0.779 & 18 \\
\hline Saprophagous species richness & S9 & 0.093 & -0.413 & 0.482 & 0.496 & 0.140 & 0.741 & 18 \\
\hline Total species richness & S9 & 0.010 & -0.470 & 0.500 & 0.555 & 0.213 & 0.832 & 18 \\
\hline Phytophagous species richness & S10 & 0.053 & -0.383 & 0.442 & 0.637 & 0.388 & 0.840 & 18 \\
\hline Saprophagous species richness & S10 & 0.156 & -0.291 & 0.575 & 0.452 & 0.080 & 0.742 & 18 \\
\hline Total species richness & S10 & 0.038 & -0.363 & 0.463 & 0.445 & 0.015 & 0.803 & 18 \\
\hline Saprophagous species abundance & S1 & 0.382 & 0.051 & 0.705 & 0.027 & -0.475 & 0.418 & 18 \\
\hline Total abundance & S4 & 0.463 & 0.040 & 0.796 & 0.353 & -0.062 & 0.659 & 18 \\
\hline Zoophagous species abundance & S4 & 0.368 & -0.051 & 0.715 & 0.676 & 0.472 & 0.838 & 18 \\
\hline Phytophagous species abundance & S9 & 0.230 & -0.378 & 0.687 & 0.677 & 0.448 & 0.827 & 18 \\
\hline Total abundance & S9 & -0.080 & -0.615 & 0.425 & 0.528 & 0.069 & 0.839 & 18 \\
\hline Saprophagous species abundance & S10 & 0.088 & -0.404 & 0.580 & 0.561 & 0.280 & 0.780 & 18 \\
\hline Total abundance & S10 & -0.020 & -0.460 & 0.479 & 0.515 & 0.168 & 0.789 & 18 \\
\hline Zoophagous species abundance & $\mathrm{S} 12$ & 0.187 & -0.369 & 0.679 & 0.631 & 0.415 & 0.805 & 16 \\
\hline Total abundance & S12 & 0.183 & -0.265 & 0.629 & 0.476 & 0.149 & 0.749 & 16 \\
\hline
\end{tabular}

Values of Pearson correlation coefficients R and 95\% confidence intervals calculated by bootstrapping. Significant R values are in bold. Only variables having at least one significant $\mathrm{R}$ value are included. For explanations of sample plot designations see Table 1

ingly, that practically all the dry plots showed a statistically significant increase in species richness and/or abundance of flies. Humid sample plots had no statistically significant trends, except for the humid calcareous grassland (S9) and poor fen (S10) where introduction of wild herbivores took place in 2005. It should be noted that during trend analysis of pooled data these sample plots were omitted. Increase of flies in these sample plots can be explained by specific biological properties of certain groups of flies. Diptera larvae are among the most active decomposers of large herbivore feces (Laurence, 1953; 1954; 1955; Smith, 1989; Gobat et al., 2004; Courtney et al., 2009). Species of Sepsidae and Scatophagidae are regarded as indicators of presence of large amount of animal feces in the territory (Annex). The observed increase in phytophagous species abundance and richness within these habitats might be connected with certain indirect effects of grazing intensity and trampling of soil. The greater abundance of some phytophagous flies in short swards may reflect the greater availability of both oviposition sites and young grass tillers suitable for larval penetration under close grazing (Southwood and Jepson 1962; Henderson and Clements 1977; Purvis and Curry, 1981; East and Pottinger, 1983).

Apart from the changes recorded in sample plots affected by introduction of large herbivores statistically signifi- cant trends were recorded within some other sample plots. It is important to determine whether these changes can be explained by climate warming and to explain the difference in the behaviour of fly communities between dry and humid habitats. Some understanding of these changes might be provided by analysis of trends in species richness and abundance of flies belonging to different trophic groups.

Of the represented trophic groups zoophagous flies showed the most pronounced increase in species richness and/or abundance during the period of study. They increased significantly in all dry sample plots (S1, S4, S5, S11, S12), and also in two humid sample plots - coastal grassland (S6) and humid deciduous forest (S7). Saprophagous flies showed significant increase in species richness and/or abundance in two dry sample plots — white dune (S5) and mesic pine forest (S12), and in one humid sample plot — humid calcareous dune slack (S2). Phytophagous flies significantly increased only in two dry sample plots - white dune (S5) and dry pine forest (S4). Thus, fly communities of dry xerophytic and mesophytic sample plots showed the most pronounced positive trends in species richness and abundance.

The effect of climate warming can be further assessed by species richness correlations with positive temperature sums. No significant correlations were found between 
pooled species richness data and meteorological data. However, some significant correlations were found between species richness and/or abundance of flies and annual sums of positive temperatures for several dry sample plots — acidic grassland alongside Lake Engure (S1), dry pine forest on gray dune on poor mineral soil (S4), and mesic pine forest on mineral soil (S12) as well as for two humid sample plots - humid pine forest in shallow dune slack (S3) and humid deciduous forest on mineral soil (S7). Exceptions occurred for the humid calcareous grassland (S9) and poor fen (S10) which had significant correlations between temperature and total abundance and species richness of flies as well as between temperature and species richness and/or abundance of all trophic groups. However, we considered these correlations as misleading taking into account the effect of introduction of large herbivores to these sample plots in 2005 .

Again, the largest number of statistically significant correlations with temperature (three for dry and two for moist sample plots) were for zoophagous diptera. Therefore, it can be concluded that climate warming could have positive effects on species richness and numbers of zoophagous flies. However, it should be noted that increase in species richness of these flies evidently occurred by recruiting from local fauna of diptera, as no species of southern origin have yet been recorded until now.

Significant positive correlations with annual precipitation and community characteristics of diptera were found only in dry pine forest (S4) for total abundance and in grassland alongside Lake Engure (S1) for abundance of saprophagous flies. Both of these sample plots are located on dry sandy soils, which suffer from drought during periods of low precipitation, which is well known depressive factor for poor development of soil fauna, including saprophages (Lavelle and Spain, 2005).

We do not exclude that one of the reasons for the poor correlations between community characteristics and meteorological data might be due to averaged annual meteorological data used in calculations without taking into account possible lag effects and/or presence of critical periods for development of certain species. Such analysis, however, goes beyond the scope of this article.

The relationships found between positive temperature sums and species richness of flies do not reveal the underlying mechanisms of these changes. Therefore, it is important to assess whether there are not involved some other environmental factors confound the effect of increase in temperature, as in the case of introduction of large herbivores to two sample plots. Among such factors could be ecological successions and soil pollution by nitrogen compounds by precipitation.

The period of study 18 years was long enough for manifestation of signs of ecological successions reflected by changes in plant species composition. Changes in plant species diversity has been found to play a decisive role in species richness of soil biota (Eisenhauer et al., 2011). The most significant changes in plant communities have been observed in moist coastal grassland (S6), moist pine forest (S3), and acidic grassland along Lake (S1) (Rūsiṇa et al., 2014). However, in costal grassland according to Rūsinga's data vegetation changes were not directional but rather fluctuating because of impact of the sea. Other sites had minor changes in plant community composition during the study period (Rūsina et al., 2014). When comparing changes in fly species richness with these successional changes no correlations were found. While the plant species diversity fluctuated from year-to-year species richness of all trophic groups of flies showed statistically significant increase. Significant increase in fly species richness was observed also in those sample plots where vegetation structure remained relatively stable during the whole period of study, like in both dry pine forest plots (S4 and S11) (Rūsina et al., 2014). Therefore, successional changes in plant communities cannot be regarded as decisive factor in fly community changes.

Our long-term studies did not include measurements of nitrogen level in soils. However, obviously it would not be correct to ignore the eventual influence of nitrogen pollution to the fly communities, and at least to consider its possible direct or indirect influence based on literature data. Some information about possible amounts of nitrogen pollution to soils of our sample plots could be derived from the data of other authors (Tērauda and Nikodemus, 2006; Laivins et al., 2007; Remke et al., 2009) who carried out special studies on nitrogen pollution in soils of similar habitats of Latvia. Remke et al., 2009 described increased nitrogen accumulation in soils along the Baltic Sea dune zone. According to their calculations during the period 2000-2005 coastal habitats of Latvia have received nitrogen 3.23-7.76 $\mathrm{kg} \mathrm{ha}^{-1} \mathrm{yr}^{-1}$ from the precipitation. Similar accumulation was described also for Scots pine forests on sandy soils of Northern and Eastern Europe (Berg and Verhoef, 1998; Prietzel et al., 2006). Despite decrease in precipitation loads of nitrogen during 2000-2007, in Scots pine forests of Latvia, nitrogen concentration in forest litter has even increased 1.3-1.6 times causing eutrophication of those oligotrophic ecosystems (Laivins et al., 2007; Tērauda and Nikodemus, 2006).

From the literature (Bolan et al., 1991; Barak et al., 1997; Bobnik et al., 1997; Augustaitis et al., 2005; Jandl et al., 2012) it is known that increased nitrogen inputs causes acidification of soil. In our sample plots, acidification was clearly indicated by changes in Ellenberg values calculated for the plant communities in the white dune (S5) and in humid coastal grassland (S6) habitats (Rūsina et al., 2014). Evidently these habitats have received significant amounts of nitrogen.

There is little information on nitrogen pollution effects on soil dwelling Diptera larva, except short notes on Sciaridae and soil Chironomidae larvae in poor mountain soils which were not affected even after four-year experiment of simulated increase in temperature and nitrogen deposition (Hågvar and Klanderund, 2009). 
Significant increase in species richness of zoophagous diptera as representatives of the higher trophic level of soil community within the dry sites should be regarded as an indirect indication of quantitative enrichment of the soil animal community. Adult Asilidae, Empididae and Scathophagidae feed on other insects, including smaller Diptera (Ferrar, 1987). Data on soil-dwelling predaceous diptera larvae are nearly absent. Asilidae and Therevidae of desert soils have been found to attack larvae of Tenebrioidae beetles (Krivosheina, 2012). Larvae of Dolichopodidae were found to feed on oligochaetes and nematodes (LaSalle and Bishop, 1990).

As we have no data on other groups of soil fauna of studied sample plots our hypotheses regarding increased richness of the soil fauna can not be yet tested. Data on the effects of increased nitrogen loads on the soil fauna are contradictory. Larger doses initially had negative effects on most groups of soil animals (Lohm et al., 1977; Xu et al., 2009; Sun et al., 2013). Moderate doses caused contrasting responses of closely related species, and reduction in species richness (Hågvar and Klanderund, 2009).

If such a decline in soil communities had occurred in our long-term research plots, then increase in species richness of zoophagous flies would have been unlikely. However, most of the results mentioned above were obtained from short term experiments which can sometimes give a false impression of system behaviour and long-term responses to $\mathrm{N}$, they always observe transient behaviour (Cannel and Thornley, 2000). In nature, a large proportion of terrestrial ecosystems are N-limited, including most temperate and boreal forests, and temperate grasslands (Aerts and Chapin, 2000). Studies of the effects of long-term nitrogen deposition in coniferous forests of Austria (Jandl et al., 2012) demonstrated that despite of high deposition rates, increase in forest stand density and productivity even increased the nitrogen demand. The transnational monitoring programme established by ICP Forests indicates that, at the large-scale, forest condition has deteriorated far less severely than was feared back in the early 1980s. High nitrogen inputs, and possibly higher temperature, were increasing forest growth (Anonymous, 2010b). Therefore, the climate warming appears to be an important background factor allowing the ecosystems to cope with additional $\mathrm{N}$ inputs and increase its productivity. There were no strong signs of soil eutrophication indicated by plant community structure at the investigated sites (Rūsinga et al., 2014).

Humid and dry habitats might differ in their response to nitrogen inputs. Excessive moisture is unfavourable for most of soil animal groups and inhibits aerobic organic matter degradation processes (Vepraskas et al., 2001). Of the humid sites, only vegetation of S6 was changing towards dryer conditions, while others had minor changes in plant community composition (Rūsinga et al., 2014). This could have been due to climate change via a decrease of Lake Engure water level since 1997 (Lizuma et al., 2010). Evidently, a change to more mesic conditions due to climate

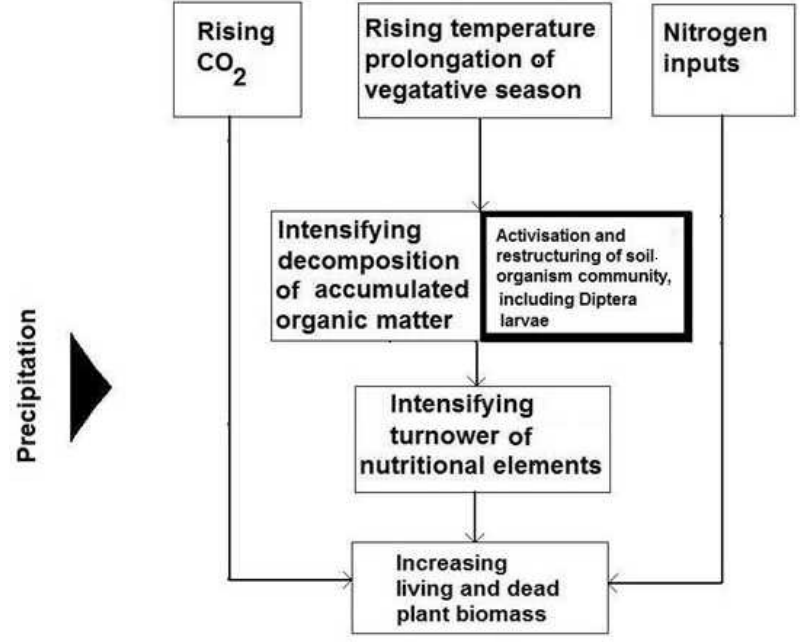

Fig. 6. Block chart illustrating hypothesis of interactive effects of climate warming with deposition, $\mathrm{CO}_{2}$ and nitrogen deposition on Diptera. For explanations see in the text.

change could be one of the reasons of a slight increase in fly species richness in the humid habitats.

The effects of climate change on soil biota are interactive rather than additive (Hågvar and Klanderund, 2009; Wan et al., 2007; Sun et al., 2013). For explanation of changes observed in fly species richness of studied sites we raise forward the following hypotheses (Fig. 6). Four environmental factors are directly or indirectly involved in fly community changes. These are: (i) climate warming, (ii) deposition rates, (iii) increase of the level of $\mathrm{CO}_{2}$, and (iv) nitrogen pollution. The last two factors, on a background of rising temperature and prolongation of vegetative season, promote increase in plant biomass and amount of litter. Rising temperature accelerates decomposition of dead organic matter (see review Conant et al., 2011), and promotes the microbial and soil animal community. A moderate amount of precipitation is of high importance for maintaining favourable soil moisture regime: both, excessive drought or moisture negatively affects soil animal communities and hence decomposition of dead organic matter. Flies, most of which are connected with soil sees to be a good indicator of those ecological processes.

More detailed analysis performed on the species level coupled with vegetation data, is necessary to obtain further insight on processes determining changes in Diptera community structure.

\section{ACKNOWLEDGEMENTS}

The study was performed by the Latvia LTER in the framework of the following national research projects financed by Latvian Council of Science: 02.0009 (1995-2001); 15.1-008 (2002-2005); 6.0033 (2006-2010), and 10.0004 (2010-2013). The authors would like to thank Solvita Rüsina for providing the data on classification of plant communities of sample plots, and to the unknown reviewer for valuable comments which allowed improve the article. 


\section{REFERENCES}

Aerts, R., Chapin, F. S. III (2000). The mineral nutrition of wild plants revisited: A re-evaluation of processes and patterns. Advances Ecol. Res., 30, $2-69$.

Anonymous (2007). Interpretation Manual of European Union Habitats. EUR 27. European Commission DG Environment. 144 pp.

Anonymous (2010a). Dabas parks „Engures ezers”. Dabas aizsardzības plāns. Engures novads, Rojas novads, Tukuma novads, Talsu novads. Plāns izstrādāts laika posmam no 2011. gada līdz 2025. gadam [Nature Park „Lake Engure”, Nature conservation plan. Engure Municipality, Roja Municipality, Tukums Municipality, Talsi Municipality. Plan developed for the period 2011-2025]. SIA „Eiroprojekts”. 104 pp. (in Latvian).

Anonymous (2010b). Europe's forests 1985-2010. 25 years of Monitoring Forest Conditions by ICP Forests. Hamburg. 12 pp.

Augustaitis, A., Augustaitiene, I., Kliučius, A., Bartkevičius, E., Mozgeris, G., Šopauskiene, D., Eitminavičiūte, I., Arbačiauskas, K., Mažeikyte, R., Baužiene, I. (2005). Forest biota under changing concentration in acidifying components in the air and their deposition. Baltic Forestry, 11 (2), $84-93$.

Aunin̄̌s, A. (Ed.) (2010). Eiropas Savienības aizsargājamie biotopi Latvijā. Noteikšanas rokasgrāmata [European Union Protected Habitats in Latvia. Manual]. Rīga: Latvijas Dabas fonds. 320 lpp.

Bale, J. S., Masters, G. J., Hodkinson, I. D., Awmack, C., Bezemer, T. M., Brown, V. K., Butterfield, J., Buse, A., Coulson, J. C., Farrar, J., Good, J. E. G., Harrington, R., Hartley, S., Jones, T. H., Lindroth, R. L., Press, M. C., Symrnioudis, I., Watt, A. D., Whittaker, J. B. (2002). Herbivory in global climate change research: Direct effect of rising temperature on insect herbivores. Global Change Biol., 8, 1-16.

Barak, P., Jobe, B. O., Krueger, A. R., Peterson, L. A., Laird, D. A. (1997). Effects of long-term soil acidification due to nitrogen fertilizer inputs in Wisconsin. Plant Soil, 197, 61-69.

Berg, M. P., Verhoef, H. A. (1998). Ecological characteristics of a nitrogen-suturated coniferous forest in the Netherlands. Biol. Ferti. Soils, 26, 258-267

Bobbink, R., Roelofs, J. G. M., Verstraten, J. M. (1997). Effects of atmospheric deposition on non-forest ecosystems in the Netherlands. In: Heij, G. M., Erisman, J. W. (eds.). Acid Atmospheric Deposition and its effects on Terrestrial Ecosystems in the Netherlands (pp. 129-158). Studies in Environmental Science, Vol. 69. Elsevier.

Bolan, N. S., Hedley, M. J., White, R. E. (1991). Processes of soil acidification during nitrogen cycling with emphasis on legume based pastures. Plant Soil, 134, 53-63.

Cannel, M. G. R., Thornley, J. H. M. (2000). Nitrogen states in plant ecosystems: A viewpoint. Ann. Bot., 86, 1161-1167.

Chapin, F. S., Zavaleta, E. S., Eviner, V. T., Naylor, R. L., Vitousek, P. M., Reynolds, H. L., Hooper, D. U., Lavorel, S., Sala, O. E., Hoddie, S. E., Mack, M. C., Diaz, S. (2000). Consequences of changing biodiversity. Nature, 405, 234-242.

Chris, D. T., Alison, C., Rhys, E. G., Michel, B., Linda, J. B., Yvonne, C. C., Barend, F. N. E., Marinez, F. S., Alan, G., Lee, H., Lesley, H., Brian, H., van Jaarsveld, A. S., Guy, F. M., Lera, M., Ortega-Huerta, M. A., Peterson, A. T., Oliver, L. P. , Stephen, E. W. (2004). Extinction risk from climate change. Nature, 427, 145-148.

Conant, R. T., Ryan, M. G., Ågren, G. I ., Birge, H. E., Davidson, E. A., Eliasson, P. E., Evans, S. E., Frey, S. D., Giardina, C. P., Hopkins, F. M., Hyvönen, R., Kirschbaum, M. U. F., Lavallee, J. M., Feld, J. L., Parton, W. J., Steinweg, J. M., Wallenstein, M. D., Wetterstedt, J. Å. M., Bradford, M. A. (2011). Temperature and soil organic matter decomposition rates synthesis of current knowledge and a way forward. Global Change Biol., 17 (11), 3392-3404.

Cothran, W. R., Summers, C. G. (1972). Sampling for the Egyptian Alfalfa Weevil: A comment on the Sweep-Net Method. J. Econ. Entomol., 65 (3), 689-691.
Courtney, G. W., Pape, T., Skevington, J. H., Sinclair, B. J. (2009). Chapter 9. Biodiversity of Diptera. In: Foottit, R., Adler, P. (eds.). Insect Biodiversity: Science and Society (pp. 185-222). Oxford: Blackwell Publishing, Ltd.

Davison, A. C., Hinkley, D. V. (1997). Bootstrap Methods and Their Application. Cambridge: Cambridge University Press. 582 pp.

East, R., Pottinger, R. P. (1983). Use of grazing animals to control insect-pests of pasture. New Zealand Entomol., 7 (4), 352-359.

Eisenhauer, N., Milcu, A., Sabais, A. C. W., Bessler, H., Brenner, J., Engels, C., Klarner, B., Maraun, M., Partsch, S., Roscher, C., Schonert, F., Temperton, V. M., Thomisch, K., Weigelt, A., Weisser, W. W., Scheu, S. (2011). Plant diversity surpasses plant functional groups and plant productivity as driver of soil biota in the long term. PLOS ONE 6(1), e16055. doi:10.1371/journal.pone.0016055.

Ferrar, P. (1987). A guide to the breeding habits and immature stages of Diptera Cyclorrapha. Part I. Entomonograph, 8, 1-478.

Frouz, J. (1999). Use of soil dwelling Diptera (Insecta, Diptera) as bioindicators: A review of ecological requirements and response to disturbance. Agricult. Ecosyst. Environ., 74, 167-186.

Gavrilova, G., Laiviňš, M., Priede, A., Medene, A. (2011). Alien flora in the Lake Engure Nature Park. Proc. Latvian Acad. Sc., Section B, 65 (5/6), 154-163.

Gobat, J.-M., Aragno, M., Matthey, W. (2004). The Living Soil: Fundamentals of Soil Science and Soil Biology. Enfield: Science Publishers, Inc. 602 pp.

Gotelli, N. J., Ellison, A. E. (2004). A Primer of Ecological Statistics. Sunderland, Mass: Sinauer Associates, Inc. Publishers. 510 pp.

Grichanov, I. Ya. (2006). A checklist and keys to North European genera and species of Dolichopodidae (Diptera). In: Plant Protection News. Supplement. St. Petersburg, VIZR RAAS. 120 pp.

Hågvar, S., Klanderund, K. (2009). Effect of simulated environmental change on alpine soil arthropods. Global Change Biol., 15 (12), 2972-2980.

Hendersoni, F., Clements, R. O. (1977). Stem-boring Diptera in grassland in relation to management practice. Ann. Appl. Biol., 87, 524-527.

Hennig, W. (1973). Diptera. In: Beier, M. (Ed.), Handbuch der Zoologie, IV. Arthropoda. 2. Insecta (337 pp.). Berlin and New York: De Gruyter.

Hickling, R., Roy, D. B, Hill, J. K., Fox, R., Thomas, C. D. (2006). The distributions of a wide range of taxonomic groups are expanding polewards. Global Change Biol., 12, 450-455.

Hill, J. K., Thomas, C. D., Fox, R., Telfer, M. G., Willis, S. G., Asher, J., Huntley, B. (2002). Responses of butterflies to twentieth century climate warming: Implications for future ranges. Proc. Royal Soc. London. Series B: Biological Sciences, 269, 2163-2171.

Holdridge, L. R. (1967). Life Zone Ecology. San José: Tropical Science Center. 206 pp.

Hughes, L. (2000). Biological consequences of global warming: Is the signal already apparent? Trends Ecol. Evol., 15, 56-61.

Hövemeyer, K. (1999). Diversity patterns in terrestrial dipteran communities. J. Animal Ecol., 68, 400-416.

Hövemeyer, K. (2000). Ecology of Diptera. In: Papp, L., Darvas, B. (eds.). Contributions to a Manual of Palaearctic Diptera. Vol. 1, General and Applied Dipterology (pp. 437-489). Budapest: Science Herald.

Jandl, R., Smidt, S., Mutsch, F., Fürst, A., Zechmeister, H., Bauer, H., Dirnböck, T. (2012). Acidification and nitrogen eitrophication of Austrian forest soils. Appl. Environ. Soil Sci., 2012, Article ID 632602. 9 pp.

Juceviča, E., Melecis, V. (2002). Long-term dynamics of Collembola in pine forest ecosystem. Pedobiologia, 46, 365-372.

Juceviča, E., Melecis, V. (2006). Global warming affect Collembola community: A long-term study. Pedobiologia, 50, 177-184. 
Karpa, A. (2000). Flies (Diptera, Brachycera) of the Lake Engures (Engure) Nature Park. Proc. Latvian Acad. Sci. Sect. B, 54, 203-212.

Kḷavin̄š, M., Rodinovs, V., Kokorīte, I. (2002). Chemistry of Surface Waters in Latvia. Riga: University of Latvia. 286 pp.

Krivosheina, N. P. (2012). Contribution to the study of the biology of soil-dwelling Diptera larvae (Insecta, Diptera) of the desert zone. Biol. Bull., 39 (3), 250-257.

Laivins, M., Rusina, S., Frolova, M., Lyulko, I. (2007). Pine Forest Vegetation Dynamics at ICP IM Sites in Latvia. In: Kleemola S., Forsius M (eds.). 16th Annual Report 2007. UNECE Convention on Long-range Transboundary Air Pollution. International Cooperative Programme on Integrated Monitoring of Air Pollution Effects on Ecosystems. The Finnish Environment, 26 (pp. 37-56). Helsinki: Finnish Environment Institute.

LaSalle, M. W., Bishop, T. D. (1990). Food habits of two larval flies (Dolichopodidae: Diptera) in two gulf coast oligohaline tidal marshes. Estuaries, 13 (3), 341-348.

Laurence, B. R. (1953). Some Diptera bred from Cow dung. Entomol. Monthly Magazine, 89, 281-283.

Laurence, B. R. (1954). The larval inhabitants of cow pats. J. Anim. Ecol., 23, 234-260.

Laurence, B. R. (1955). Flies associated with cow dung. Entomol. Record J. Var., 67, 123-126.

Lavelle, P., Spain, A. V. (2005). Soil Ecology. The Netherlands: Springer. 654 pp.

Lizuma, L. (2000). An analysis of long-term meteorological data series in Riga. Folia Geogr., 7, 53-61.

Lizuma, L., Briede, A., Kḷavin̄š, M. (2010). Long-term changes of precipitation in Latvia. Hydrol. Res., 41 (3-4), 241-252.

Lohm, U., Lundquist, H., Persson, T., Wren, A. (1977). Effects of nitrogen fertilization on the abundance of enchytraeids and microarthropods in Scots pine forests. Studia Forestalia Suectca, 140, 1-23

McCarry, J. P. (2001). Ecological consequences of recent climate change. Conserv. Biol., 15 (2), 320-331.

Melecis, V. (2000). Integrated research: The renaissance of ecology in Latvia. Proc. Latvian Acad. Sci. Sect. B, 54 (5/6), 221-225.

Melecis, V., Karpa, A., Spungisis, V. (1998). The grass-dwelling arthropod communities of the coastal reserve "Randu plavas" in Latvia. Latvijas Entomologs, 36, 55-65.

Melecis, V., Karpa, A., Spunggis, V. (2000). Assessment of the strategy used for insect population monitoring in the Lake Engures (Engure) Nature Park, Latvia. Lake Engure, Latvia. Proc. Latvian Acad. Sci. Sect. B, 54 (5/6), 197-202.

Melecis, V., Karpa, A., Kabucis, I., Savičs, F., Liepiņa, L. (1999). Influence of vegetation structure on the distribution of grass-dwelling arthropods of salty coastal meadows. In: Proceedings of the XXIV Nordic Congress of Entomology, August 8-11, Tartu, Estonia (pp. 101-110). Tartu.

Melecis, V., Vīksne, J., Sprinğge, G., Briede, A. (2005). Long-term ecological research in Latvia. Acta Zoologica Lithuanica, 15 (2), 142-145.

Menéndez, R. (2007). How are insects responding to global warming? Tijdschrift voor Entomologie, 150, 355-365.

Meuffels, H. J. G., Grootaert, P. (1990). The identity of Sciapus contristans (Wiedemann, 1817) (Diptera: Dolichopodidae), and a revision of the species group of its relatives. Bulletin de l'institut royal des sciences naturelles de Belgique, Entomologie, 60, 161-178.

Parmesan, C. (2006). Ecological and evolutionary responses to recent climate change. Annu. Rev. Ecol. Evol. Syst., 37, 637-669.

Parmesan, C., Yohe, G. (2003). A globally coherent fingerprint of climate change impacts across natural systems. Nature, 421, 37-42.
Pearson, R. G., Dawson, T. P. (2003). Predicting the impacts of climate change on the distribution of species: Are bioclimate envelope models useful? Global Ecol. Biogeogr., 12, 361-371.

Pollet, M. (1990). Phenetic and ecological relationships between species of the subgenus Hercostomus (Gymnopternus) in western Europe with the description of two new species (Diptera: Dolichopodidae). Syst. Entomol., 15, 359-382.

Pollet, M. (1996). Systematic revision and phylogeny of the Palaearctic species of the genus Achalcus Loew (Diptera: Dolichopodidae) with the description of four new species. Syst. Entomol., 21, 353-386.

Prietzel, J., Stetter, U., Klemmt, H.-J., Rehfuess, K. (2006). Recent carbon and nitrogen accumulation and acidification in soils of two Scots pine ecosystems in Southern Germany. Plant Soil, 289 (1/2), 153-170.

Purvis, G., Curry, J. P. (1981). The influence of sward management on foliage arthropod communities in a ley grassland. J. Appl. Ecol., 18, 711-725.

Remke, E., Brouwer, E., Kooijman, A., Esselink, I. B., Roelofs, J. G. M. (2009). Even low to medium deposition impacts vegetation of coastal dunes around the Baltic Sea. Environ. Poll., 157 (3), 792-800.

Remm, E., Elberg, K. (1979). Terminalia of the Lauxaniidae (Diptera) found in Estonia, Latvia and Lithuania. In: Elberg, K. (Ed.). Dipteroloogilisi uurimusi (pp. 66-117). Tartu: Esti NSV Teaduste Akadeemia.

Rodwell, J. S., Schaminee, J. H. J., Mucina, L., Pignatti, S., Dring, J., Moss, D. (2003). The Diversity of European Vegetation. Wageningen: National Reference Centre for Agriculture, Nature and Fisheries. 168 pp.

Root, T. L., Price, J. T., Hall, K. R., Schneider, S. H., Rosenzweig, C., Pounds, J. A. (2003). Fingerprints of global warming on wild animals and plants. Nature, 421 (6918), 57-60.

Roy, D. B., Sparks, T. H. (2000). Phenology of British butterflies and climate change. Global Change Biol., 6, 407-416.

Rūsina, S., Gavrilova G., Roze I., Šulcs V. (2014). Temporal species turnover and plant community changes across different habitats in the Lake Engure Nature Park, Latvia. Proc. Latvian Acad. Sci. Sect. B, 68 (1/2), 66-79.

Sala, O. E., Chapin, F. S. III, Armesto, J. J., Berlow, E., Bloomfield, J., Dirzo, R., Huber-Sanwald, E., Huenneke, L. F., Jackson, Wall, D. H. (2000). Global biodiversity scenarios for the year 2100. Science, 287, 1770-1774.

Schowalter, T. D. (2000). Insect Ecology. An Ecosystem Approach. Elsevier, 576 pp.

Smith, K. G. V. (1989). An Introduction to the Immature Stages of British Flies. Diptera larvae, with Notes on Eggs, Puparia, and Pupae. London: Royal Entomological Society. 166 pp.

Southwood, T. R. E. (1996). Natural communities: Structure and dynamics. Philosoph. Transact. Royal Soc. Lond., Sect. B, 351, 1113-1129.

Southwood, T. R. E., Jepson, W. F. (1962). The productivity of grasslands in England for Oscinella frit (L.) (Chloropidae) and other stem-boring Diptera. Bull. Entomol. Res., 53, 395-407.

Stuart, L. P. (2008). Biodiversity: Climate change or habitat loss — which will kill more species? Curr. Biol., 18, R117-R119.

Sun, X., Zhang, X., Zhang, S., Dal, G., Han, S., Liang, W. (2013). Soil nematode response to increases in nitrogen deposition and precipitation in a temperate forest. PLOS ONE, 6 (13). DOI: 10.1371/journal.pone.0082468.

Tērauda, E., Nikodemus, O. (2006). Element inputs by litterfall to the soil in pine forest ecosystems. Environ. Bioind., 1 (2), 145-156.

Vepraskas, M. J., Craft C. B., Richardson J. L. (2001). Wetland Soils: Genesis, Hydrology, Landscapes, and Classification. Boca Raton: CRC Press LLC. $432 \mathrm{pp}$.

Vìksne, J. (2000). Changes of nesting bird fauna at the Engure Ramsar site, Latvia, during the last 50 years. Proc. Latv. Acad. Sci. Sect. B., 54 (5/6), 213-220. 
Walther, G.-R. (2010). Community and ecosystem responses to recent climate change. Philos. Transact. Royal Soc. B: Biological Sciences, 365, 2019-2024.

Walther, G.-R., Post, E., Convery, P., Menzel, A., Parmesan, C., Beebee, T. J. C., Fromentin, J.-M., Hoegh-Guldberg, O., Bairlein, F. (2002). Ecological responses to recent climate change. Nature, 416 (6879), 389-395.

Wan, S. Q., Norby, R. J., Ledford, J., Weltzin, J. F. (2007). Responses of soil respiration to elevated $\mathrm{CO}$, air warming, and changing soil water availability in a model oldfield grassland. Global Change Biol., 13, 2411-2424.

Received 11 March 2014
Xu, G. L., Schleppi P., Li M. H., Fu S. L. (2009). Negative responses of Collembola in a forest soil (Alptal, Switzerland) under experimentally increased N deposition. Environ. Poll., 157, 2030-2036.

Бей-Биенко Г. Я. (ред.) (1969). Определитель насекомых Европейской части СССР. Двукрылые, блохи. Том 5, ч. 1 [Bei-Bienko, G. Identification keys of insects of European part of USSR, Two-winged insects, bugs]. Ленинград: Наука, 807 с.

Бей-Биенко Г. Я. (ред.) (1970). Определитель насекомых Европейской части СССР. Двукрылые, блохи. Том 5, ч. 2 [Bei-Bienko, G. Identification keys of insects of European part of USSR, Two-winged insects, bugs]. Ленинград: Наука. 943 с.

\section{DIVSPĀRN̦U (DIPTERA, BRACHYCERA) SKAITA UN SUGU BAGĀTĪBAS IZMAIṆAS ENGURES EZERA DABAS PARKĀ: VAI KLIMATA PASILTINĀŠANĀS EFEKTS?}

Rakstā apskatîtas divspārṇu (Diptera, Brachycera) skaita un sugu bagātības izmaiṇas laikā no 1995. gada līdz 2012. gadam 12 Engures ezera dabas parka pastāvīgajos parauglaukumos. Pētījumi veikti Latvijas nacionālā Ilgtermiṇa ekoloğisko pētījumu (LTER) tīkla ietvaros. Pētījumu periodā pēc vietējās meteostacijas datiem konstatēts statistiski būtisks $\left(\mathrm{R}^{2}=0.489 ; P<0.01\right)$ pozitīvo temperatūru $\left(>4{ }^{\circ} \mathrm{C}\right)$ summas pieaugums. Kukaiṇi ievākti trīs reizes sezonā (jūnijs, jūlijs, augusts) ar entomoloğisko tīkliṇa „pḷāvienu” metodi, virzoties pa noteiktu maršrutu parauglaukumā. Ievāktajā materiālā noteiktas 411 mušu sugas no 35 dzimtām. Parauglaukumi tika sadalīti divās grupās - sausie, ksero- un mezofìtiskie un mitrie higrofìtiskie biotopi. Gandrīz visos sausajos parauglaukumos konstatēts statistiski būtisks mušu sugu bagātības un/vai indivīdu skaita pieaugums. Mitrajos parauglaukumos statistiski būtiskas izmaiņas netika konstatētas, izṇemot divos mitro pḷavu biotopos, kur 2005. gadā uzsākta zālāju apsaimniekošana, ieviešot lielos savvaḷas zālēdājus. Apvienojot parauglaukumu datus, izṇemot tos, kuros tika ieviesti zālēdāji, konstatēts statistiski būtisks sugu bagātības pieaugums $\left(\mathrm{R}^{2}=0.647 ; P<0.01\right)$. No trim trofiskajām grupām - zoofāgiem, fitofāgiem un saprofāgiem - zoofāgiem konstatēts vislielākais statistiski būtisko pozitīvo trendu skaits, pa lielākai daḷai tieši sausajos parauglaukumos. Vairākos parauglaukumos konstatēta statistiski būtiska pozitīva sugu bagātības un skaita korelācija ar pozitīvo temperatūru summu. Izvirzīta hipotēze par iespējamu netiešo klimata pasiltināšanās ietekmi uz sugu bagātỉbu mijiedarbībā ar tādiem faktoriem kā mitruma režīms, slāpekḷa piesārṇojums un veǵetācijas struktūra. 
A N N E X

SPECIES LIST OF FLIES (DIPTERA, BRACHYCERA) COLLECTED AT 12 LONG-TERM SAMPLE PLOTS OF THE LAKE ENGURE NATURE PARK IN 1995-2012*

\begin{tabular}{|c|c|c|c|c|c|c|c|c|c|c|c|c|}
\hline \multirow[t]{2}{*}{ Taxon } & \multicolumn{12}{|c|}{ Sample plot } \\
\hline & S1 & $\mathrm{S} 2$ & S3 & S4 & S5 & S6 & $\mathrm{S} 7$ & S8 & S9 & $\mathrm{S} 10$ & S11 & $\mathrm{S} 12$ \\
\hline \multicolumn{13}{|l|}{$\underline{\text { Rhagionidae }}$} \\
\hline Rhagio lineola (Fabricius, 1794) & 2 & & 22 & & & & 2 & & & & 5 & 5 \\
\hline R. maculatus (De Geer, 1776) & & & & & & & & & & & 2 & \\
\hline R. scolopaceus (Linnaeus, 1758) & & & 3 & & & & 14 & & 1 & & & \\
\hline R. tringarius (Linnaeus, 1758) & & & & & & 1 & 2 & & & & & \\
\hline \multicolumn{13}{|l|}{ Tabanidae } \\
\hline Chrysops divaricatus (Loew, 1858) & & & & & & 2 & & & 1 & 2 & & \\
\hline Haematopota pluvialis (Linnaeus, 1758) & 3 & 7 & 2 & 5 & 3 & 7 & 3 & 8 & 14 & 35 & 1 & 2 \\
\hline \multicolumn{13}{|l|}{$\underline{\text { Stratiomyidae }}$} \\
\hline Nemotelus nigrinus (Fallén, 1817) & & & & & & & & 1 & & & & \\
\hline N. pantherinus (Linnaeus, 1758) & & & & & & & & 5 & & & & \\
\hline N. uliginosus (Linnaeus, 1767) & & & & & & & & 2 & & & & \\
\hline Odontomyia hydroleon (Linnaeus, 1758) & & 2 & & & & & & & & & & \\
\hline Oplodontha viridula (Fabricius, 1775) & & & & & 1 & 2 & & 1 & 13 & 12 & & \\
\hline Oxycera trilineata (Linnaeus, 1767) & & & & & & & & & 1 & & & \\
\hline Stratiomys furcata (Fabricius, 1794) & & 1 & & & & & & & & & & \\
\hline \multicolumn{13}{|l|}{ Asilidae } \\
\hline Dioctria hyalipennis (Fabricius, 1794) & & & & & & & & & & 1 & 5 & 2 \\
\hline Lasiopogon cinctus (Fabricius, 1781) & & & 1 & & & & & & & & & \\
\hline Leptogaster cylindrica (De Geer, 1776) & 1 & & 1 & & & & & & 5 & 5 & & \\
\hline Machimus atricapillus (Fallén, 1814) & 15 & & 2 & 2 & 5 & 4 & & & 1 & 1 & & \\
\hline M. cingulatus (Fabricius, 1781) & & & & & 1 & & & & & & & \\
\hline Neoitamus cyanurus (Loew, 1849). & 4 & & & 1 & & & & & & & & \\
\hline Philonicus albiceps (Meigen, 1820) & & & & & 5 & & & & & & & \\
\hline \multicolumn{13}{|l|}{ Therevidae } \\
\hline Acrsathe annulata (Fabricius, 1805) & & & & & & & & & & & 1 & \\
\hline \multicolumn{13}{|l|}{ Hybotidae } \\
\hline Bicellaria intermedia (Lundbeck, 1910) & 1 & & 13 & 2 & 1 & & & 13 & & & 8 & 303 \\
\hline B. pilosa (Lundbeck, 1910) & & & & & & & & & & & 1 & \\
\hline B. vana (Collin, 1926) & 122 & 6 & 17 & 5 & 3 & 316 & 8 & 44 & 427 & 46 & 24 & 56 \\
\hline Hybos culiciformis (Fabricius, 1775) & 17 & 59 & 214 & 169 & 41 & 89 & 42 & 7 & 4 & 3 & 161 & 997 \\
\hline H. femoratus (Müller, 1776) & & 1 & 21 & 7 & & & 28 & & 3 & & & \\
\hline Stilpon graminum (Fallén,1815) & & & & 1 & 1 & 1 & & & 1 & & 2 & \\
\hline S. nubilus (Collin, 1926) & & & & & & & & & & 1 & & \\
\hline Tachydromia arrogans (Linnaeus, 1761) & & & 1 & & & & & & 1 & 1 & & \\
\hline \multicolumn{13}{|l|}{ Empididae } \\
\hline Empis albipennis (Waltl, 1837) & & & & & 1 & 5 & & & & & & \\
\hline E. bicuspidata (Collin, 1927) & & & & & & & & & 1 & & & \\
\hline E. livida (Linnaeus, 1758) & & & & & & & & & 3 & & & \\
\hline E. praevia (Collin, 1927) & & & 1 & 13 & & & & & & & & \\
\hline E. prodromus (Loew, 1867) & & & & & & & & & & 1 & 4 & 1 \\
\hline E. punctata (Meigen, 1804) & & & & & & & 3 & & & & & \\
\hline E. stercorea (Linnaeus, 1761) & 1 & & 1 & & & & 8 & & & & & \\
\hline Hemerodromia raptoria (Meigen, 1830) & & & & & & 1 & & & & & & \\
\hline Phyllodromia melanocephala (Fabricius, 1794) & 58 & 4 & 1460 & 1 & 3 & & 17 & 4 & 1 & 1 & & \\
\hline Rhamphomyia gibba (Fallén, 1816) & & & & & & 1 & & & & & 1 & \\
\hline R. nigripennis (Fabricius, 1794) & & & 2 & & 1 & 14 & 34 & & 4 & 1 & & 3 \\
\hline R. physoprocta (Frey, 1913) & & & & & & 1 & & & & & & \\
\hline R. tibiella (Zetterstedt, 1842) & & & 1 & & & & & 2 & & & & \\
\hline R. trigemina (Oldenberg, 1927) & & & & & & 2 & & & 1 & & & \\
\hline
\end{tabular}


R. ungiculata (Frey, 1913)

Dolichopodidae

Achalcus flavicollis (Meigen, 1824)

Argyra diaphana (Fabricius, 1775)

Campsicnemus curvipes (Fallén, 1823)

C. dasycnemus (Loew, 1857)

C. lumbatus (Loew, 1857)

C. picticornis (Zetterstedt, 1843)

C. scambus (Fallén, 1823)

Chrysotimus mollicus (Fallén, 1823)

C. scambus (Fallén, 1823)

Chrysotus cilipes (Meigen, 1824)

C. femoratus Zetterstedt, 1843

C. gramineus (Fallén, 1823)

C. kowarzi Lundbeck, 1912

C. neglectus (Wiedemann, 1817)

C. pulchellus Kowarz, 1874

C. suavis Loew, 1857

Dolichopus acuticornis (Wiedemann, 1817)

D. apicalis Zetterstedt, 1849

D. brevipennis Meigen, 1824

D. cilifemoratus Macquart, 1827

D. gramineus (Fallen, 1823)

D. latilimbatus (Macquart,1827)

D. latipennis (Fallén, 1823)

D. lepidus (Staeger, 1842)

D. longitarsis (Stannius, 1831)

D. migrans (Zetterstedt, 1843)

D. nigricornis (Meigen, 1824)

D. nitidus (Fallén, 1823)

D. notatus (Staeger, 1842)

D. nubilis (Meigen, 1824)

D. pennatus (Meigen, 1824)

D. picipes (Meigen, 1824)

D. planitarsis (Fallen, 1823)

D. plumipes (Scopoli, 1763)

D. popularis (Wiedemann, 1817

D. rupestris (Haliday, 1833)

D. simplex (Meigen, 1824)

D. trivialis (Haliday, 1832)

D. ungulatus (Linnaeus, 1758)

D. wahlbergi (Zetterstedt, 1843)

Hercostomus aerosus (Fallén, 1823)

H. angustifrons (Staeger, 1842)

H. assimilis (Staeger, 1842)

H. chalybeus (Wiedemann, 1817)

H. chrysozygos (Wiedemann, 1817)

H. metallicus (Stannius, 1831)

Heteronychia proxima Rondani, 1860

H. vagans (Meigen, 1826)

Leucostola vestita (Wiedemann, 1817)

Medetera jacula (Fallén, 1823)

M. plumbella (Meigen, 1824)

Neurigona quadrifassciata (F.)

Rhaphium laticorne (Fallén, 1823)

R. riparium (Meigen, 1824)

\begin{tabular}{|c|c|c|c|c|c|c|c|c|c|c|c|}
\hline & & & & & & & & & & & 1 \\
\hline & & & & & & & & & & & \\
\hline & & & & & & & & 1 & & & \\
\hline & & & & & 1 & & & & & & \\
\hline & & & 1 & & & & & & 1 & 1 & \\
\hline & & & & & & & & & 1 & & \\
\hline & & & & & & & & & & 2 & \\
\hline & & & & & & & & & 1 & & \\
\hline & & & & & 4 & & & 4 & 13 & 31 & 1 \\
\hline & & & & & & 1 & & & 1 & 2 & \\
\hline & & & & & & & & & & 3 & \\
\hline & & & & & 1 & & & 7 & & & \\
\hline 2 & 1 & & 5 & & & & & & & 1 & 1 \\
\hline 2 & & 2 & & 4 & 44 & 6 & & 16 & 63 & 1 & 2 \\
\hline & 3 & & & & 2 & & & & 1 & & \\
\hline & & & & & & 1 & & & & 1 & \\
\hline & 1 & & & 3 & 1 & & & 27 & 6 & 1 & \\
\hline & & & & 3 & 6 & & & & & & \\
\hline & & & & 11 & & & & & & & \\
\hline & & & & & & & & 1 & 2 & & \\
\hline & & & & & & & & 13 & 35 & 1 & \\
\hline & & & & & 1 & & & 2 & & & \\
\hline & & & & & 1 & & & & & & \\
\hline 4 & & & & & & & & 8 & 31 & & 1 \\
\hline & & & & 1 & & & & 1 & & & \\
\hline 3 & 1 & & & & 1 & & & & 4 & & 2 \\
\hline 2 & 2 & 5 & & & 32 & & 11 & 3 & 4 & & \\
\hline 24 & 1 & & 42 & 9 & 5 & 1 & 1 & & 3 & 44 & 3 \\
\hline 2 & & 1 & & & & & & & & & \\
\hline 6 & 19 & 9 & & 1 & 6 & & & 17 & 53 & 3 & 1 \\
\hline & & & & 2 & 17 & & & 1 & & & \\
\hline 2 & & & & 1 & 23 & & & 8 & 3 & 1 & 5 \\
\hline & & & & & 26 & 1 & & 11 & 1 & & 1 \\
\hline & & 2 & & & & & & & & & \\
\hline & & & & & & & & 1 & & & \\
\hline 5 & & 8 & 1 & 9 & 124 & 2 & & 16 & 112 & 13 & 29 \\
\hline 3 & & 8 & & & 1 & 21 & 1 & 4 & 1 & & 1 \\
\hline & & & 9 & & & & 1 & & & & \\
\hline & & & & 2 & 17 & & 2 & 27 & 27 & 1 & 21 \\
\hline & & & & & 3 & 9 & & 29 & 13 & 1 & \\
\hline 2 & 1 & & & 1 & 3 & 1 & & 13 & 18 & 2 & \\
\hline & & & & & & 2 & & & & & \\
\hline 4 & & 7 & 3 & & 7 & 11 & & 14 & 8 & 1 & 2 \\
\hline & & & & & & & 2 & 17 & 13 & 1 & 2 \\
\hline & & & & & 2 & & & 1 & 4 & & \\
\hline & & & & & 1 & & & 1 & & & \\
\hline & & & & 1 & 12 & & & & 1 & & \\
\hline 1 & 1 & 1 & & & & 4 & 1 & & & & \\
\hline & & & & & & & & & & & 1 \\
\hline & & & & & & & 1 & & & & \\
\hline & & & & & 1 & & & & & & \\
\hline & & & & & & & & 1 & 1 & & \\
\hline & & & & 1 & & & & & & & \\
\hline 4 & & & & & & 1 & & & & 4 & \\
\hline & & & & & & & & & & 1 & \\
\hline & & & & 3 & & & & & & & \\
\hline
\end{tabular}


Sympucnus aeneicoxa (Meigen, 1824)

S. annlipes (Meigen, 1824)

S. pulicarius (Fallén, 1823)

Syntormon bicolorellus (Zetterstedt, 1843)

S. pallipes (Fabricius, 1794)

S. rufipes (Meigen, 1824)

Thrypticus cuneatus (Becker, 1917)

Xantochlorus ornatus (Haliday, 1832)

X. tenellus (Wiedemann, 1817)

Syrphydae

Orthonevra intermedia (Lundbeck, 1916)

Micropezidae

Neria cibaria (Linnaeus, 1761)

Psilidae

Chyliza vittata (Meigen, 1826

Psilosoma lefebvrei (Zetterstedt, 1835)

Conopidae

Conops quadrifasciatus (Degeer, 1776)

Sicus ferrugineus (Linnaeus, 1761)

\section{Pallopteridae}

Palloptera saltuum (Linnaeus, 1758)

P. trimacula (Meigen, 1826)

\section{Opetidae}

Opetia nigra (Meigen, 1830)

Tephritidae

Acinia biflexa (Loew, 1844)

Campiglossa absinthii (Fabricius, 1805)

C. difficilis (Hendel, 1927)

Chaetostomella cylindrica (Robineau-Desvoidy, 1830)

Cryptaciura rotundiventris (Fallén, 1814)

Dioxyna bidentis (Robineau-Desvoidy, 1830)

Dithryca guttularis (Meigen, 1826)

Ensina sonchi (Linnaeus, 1767)

Noeeta pupillata (Fallén, 1814)

Oxyna flavipennis (Loew, 1844)

Sphenella marginata (Fallén, 1814)

Tephritis angustipennis (Loew, 1844)

T. bardanae (Schrank, 1803)

T. cometa (Loew, 1840)

T. conura (Loew, 1844)

T. crepidis (Hering, 1936)

T. dilacerata (Loew, 1846)

T. pulchra (Loew, 1844)

Terellia colon (Meigen, 1826)

T. ruficauda (Fabricius, 1794)

Trupanea stellata (Fuessly, 1775)

Urophora guadrifasciata (Meigen, 1826)

U. jaceana (Hering, 1935)

Xyphosia miliaria (Schrank, 1781)

Ulitidae

Herina frondescentiae (Linnaeus, 1758)

H. palustris (Meigen, 1826)

Melieria cana (Loew, 1858)

Tetanops myopina (Fallén, 1820)

Chamaemyidae

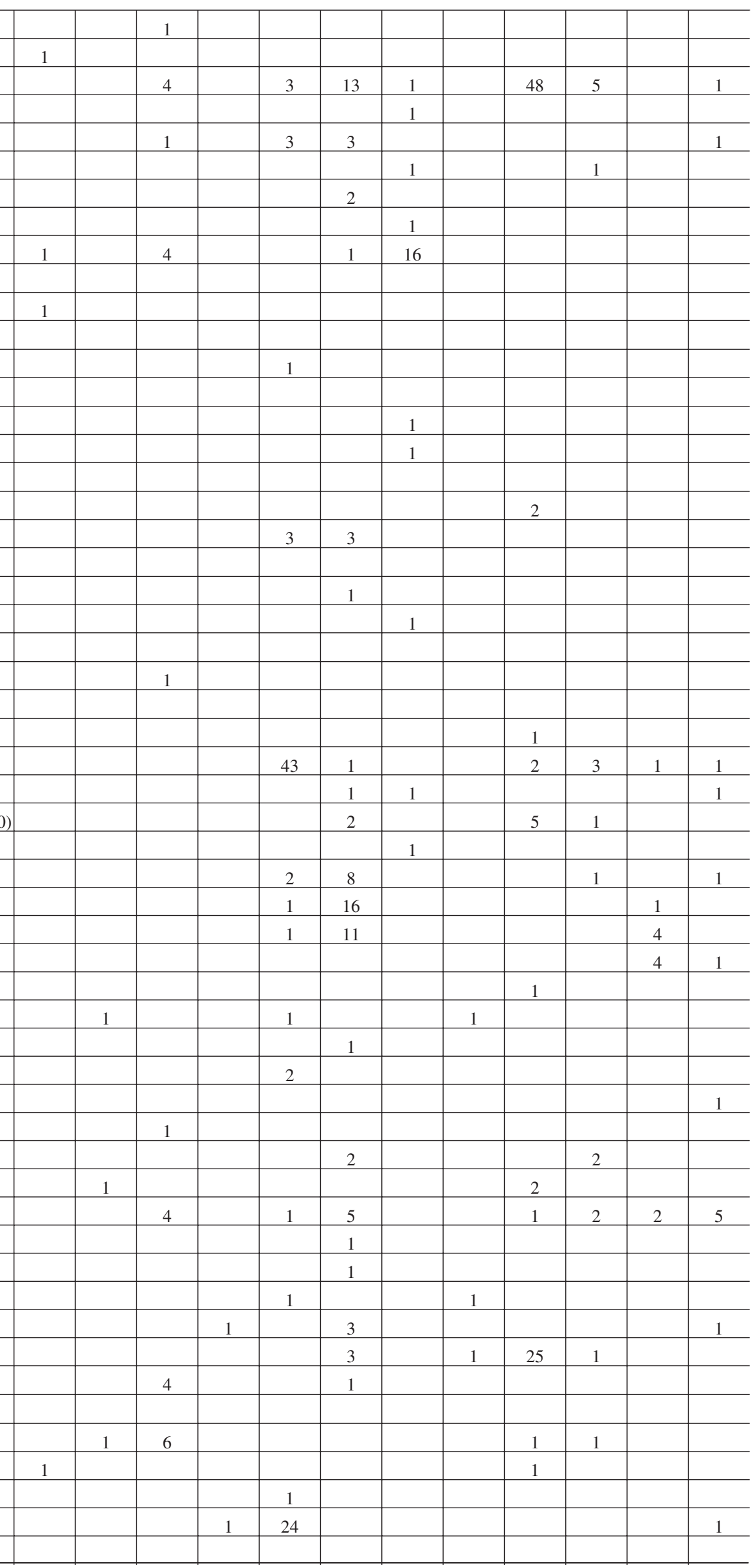


Acrometopia wahlbergi (Zetterstedt, 1846)

Chamaemyia aridella (Fallén, 1823)

C. elegans (Panzer, 1809)

C. flavipalpis (Haliday, 1838)

C. juncorum (Fallén, 1823)

C. polystigma (Meigen, 1830)

Leucopis argentata (Heeger, 1848)

L. argenticollis (Zetterstedt, 1848)

Parochthiphila spectabilis (Loew, 1858)

Lauxaniidae

Calliopum aeneum (Fallén, 1820)

C. elisae (Meigen, 1826)

Homoneura interstincta (Fallén, 1820)

Lauxania cylindricornis (Fabricius, 1794)

Meiosimyza affinis (Zetterstedt, 1847)

M. decipiens (Loew, 1847)

M. illota (Loew, 1847)

M. laeta (Zetterstedt, 1838)

$M$. rorida (Fallén, 1820)

M. subfasciata (Zetterstedt, 1838)

Minettia fasciata (Fallén, 1826)

M. longipennis (Fabricius, 1794)

M. lupulina (Fabricius, 1787)

M. rivosa (Meigen, 1826)

Peplomyza litura (Meigen, 1826)

Sapromyza hyalinata (Meigen, 1826)

S. quadripunctata (Linnaeus, 1758)

S. basalis (Zetterstedt, 1847)

S. opaca (Becker, 1895)

Tricholauxania praeusta (Fallén, 1820)

Trigonometopotus frontalis (Meigen, 1830)

Phaemyiidae

Pelidnoptera nigripennis (Fabricius, 1794)

Sciomyzidae

Antichaeta brevipennis (Zetterstedti, 1846)

Colobaea bifasciella (Fallén, 1820)

C. distincta (Meigen, 1830)

Coremacera marginata (Fabricius, 1775)

Dichetophora finlandica Verbeke, 1964

Dictya umbrarum (Linnaeus, 1758)

Ectinocera borealis Zetterstedti, 1838

Elgiva cucularia (Linnaeus, 1767)

Euthycera chaerophylli (Fabricius, 1798)

E. fumigata (Scopoli, 1763)

Hydromya dorsalis (Fabricius, 1775)

Ilione albiseta (Scopoli, 1763)

I. lineata (Fallén, 1820)

I. rossica (Mayer, 1953)

Limnia paludicola (Elberg, 1965)

L. unguicornis (Scopoli, 1763)

Pherbellia albocostata (Fallén, 1820)

P. argyra (Verbeke,1967)

P. brunnipes (Meigen, 1838)

$P$. cinerella (Fallén, 1820)

P. dubia (Fallén, 1820)

\begin{tabular}{|c|c|c|c|c|c|c|c|c|c|c|c|}
\hline & & & & & & & 9 & & 1 & & \\
\hline 32 & & & 12 & 12 & 4 & 2 & 1 & 1 & & & \\
\hline \multicolumn{12}{|l|}{2} \\
\hline & & & 1 & 12 & & & 3 & & & 1 & \\
\hline 13 & 3 & & 8 & 12 & 6 & & 7 & & & & 1 \\
\hline \multirow[t]{2}{*}{51} & 3 & 6 & 5 & 19 & 4 & 8 & 7 & 3 & 1 & 2 & 5 \\
\hline & 14 & 3 & & 1 & & & 1 & & & & \\
\hline \multirow[t]{5}{*}{1} & 2 & 16 & 4 & 4 & & & & 2 & & & \\
\hline & 157 & 5 & & & & & 225 & 1 & & 2 & \\
\hline & & 2 & & 2 & 8 & 2 & & 14 & 1 & 1 & \\
\hline & & & & 1 & 5 & 1 & 1 & 5 & & & \\
\hline & & & & & & 2 & & & & & \\
\hline 16 & & & & & 2 & 3 & 1 & & & 3 & 3 \\
\hline 1 & & & & & 2 & 9 & & & & 1 & \\
\hline \multirow[t]{2}{*}{2} & & 1 & & & 1 & 56 & & & & 1 & \\
\hline & & 3 & & & & 9 & & & & & \\
\hline \multirow[t]{2}{*}{3} & & 2 & & & 4 & 5 & & & & & \\
\hline & & 8 & & & & 176 & & & & & 1 \\
\hline \multirow[t]{3}{*}{23} & & & & 1 & & & & 1 & & 3 & \\
\hline & & & & 1 & 1 & & & & & & \\
\hline & & 4 & & & & 9 & & & & & 2 \\
\hline \multirow[t]{4}{*}{156} & & 3 & & 1 & 11 & 2 & & 1 & & 3 & 1 \\
\hline & & & & 2 & & & & & & & \\
\hline & & & & & & 9 & & & & & \\
\hline & & & & & & 7 & & & & & \\
\hline 1 & & 1 & & 2 & 1 & & & & & 1 & 1 \\
\hline \multirow[t]{12}{*}{1} & & & & & & 35 & & & & & \\
\hline & & & & & & & & & & 2 & \\
\hline & & 1 & & & & 6 & & & & & \\
\hline & & & & & & & 1 & & 1 & & \\
\hline & & 1 & & & & & & & & & \\
\hline & & & & & 1 & & & & & & \\
\hline & 2 & & & & 1 & & & 2 & 2 & & \\
\hline & & & & & & & & & 4 & & \\
\hline & & & & & 1 & 24 & & & & & \\
\hline & & & & & & & & 2 & & & \\
\hline & 19 & & & 1 & & & & & & & \\
\hline & & & & & & & & & & 1 & \\
\hline \multirow[t]{7}{*}{4} & 1 & 3 & & & & & & 1 & 7 & & 2 \\
\hline & & & & & 2 & 2 & & 1 & & & \\
\hline & & & & & & 1 & & & & & \\
\hline & & & & 1 & 1 & & & 4 & 2 & & \\
\hline & & & & & & & & & 1 & & \\
\hline & 5 & & & & & & 1 & & 1 & & \\
\hline & & & & & & & & & 6 & & \\
\hline 1 & 8 & 5 & & & 1 & 13 & 11 & 5 & & & 1 \\
\hline 3 & 6 & 14 & & 31 & 64 & 12 & 31 & 8 & 21 & 2 & 2 \\
\hline 1 & & & & & & 12 & & & & & \\
\hline \multirow[t]{4}{*}{1} & 4 & & & & 2 & 1 & 1 & & 4 & & \\
\hline & 1 & & & & & & & & & & \\
\hline & & & & & & & & 2 & & & \\
\hline & 4 & & & & & 4 & & & & & \\
\hline
\end{tabular}


P. griseicollis (Becker,1900)

P. griseola (Fallén, 1820)

P. nana (Fallén, 1820)

P. obtusa (Fallén, 1820)

$P$. pallidiventris (Fallén, 1820)

Pherbina coryleti (Scopoli, 1763)

P. intermedia (Verbeke, 1948

Psacadina vittigera (Schiner, 1864)

P. zernyi (Mayer, 1953)

Pteromicra glabricula (Fallén, 1820)

P. leucopeza (Meigen, 1838)

Sciomyza simplex Fallén, 1820

Sepedon sphegea (Fabricius, 1775)

S. spinipes (Scopoli, 1763)

Tetanocera arrogans (Meigen, 1830

T. elata (Fabricius, 1781)

T. ferruginea (Fallén, 1820

T. fuscinervis (Zetterstedt, 1838)

T. phyllophora (Melander, 1920

T. robusta (Loew, 1847)

T. silvatica (Meigen, 1830)

Trypetoptera punctulata (Scopoli, 1763)

Opomyzidae

Geomyza tripunctata (Fallén, 1823)

Opomyza germinationis (Linnaeus, 1758)

\section{Chloropidae}

Aphanotrigonum nigripes (Zetterstedt, 1848)

A. trilineatum (Meigen, 1830)

Calamoncosis duinensis (Strobl, 1909)

C. glyceriae (Nartshuk, 1958)

Calamoncosis minima (Strobl, 1893)

Centorisoma elegantulum (Becker, 1910)

Cetema cereris (Fallén, 1820)

C. elongatum (Meigen, 1830)

C. myopinum (Loew, 1866)

C. neglectum (Tonnoir, 1931)

Chlorops brevimanus (Loew, 1866)

C. calceatus (Meigen, 1830)

C. hypostigma (Meigen, 1830)

C. meigeni (Loew, 1866)

C. planifrons (Loew, 1866)

C. pumilionis (Bjerkander, 1778)

C. speciosus (Meigen, 1830)

C. troglodytes (Zetterstedt, 1848)

C. varsoviensis (Becker, 1910)

C. zonulatus (Wahlgren, 1913)

Conioscinella frontella (Fallén, 1820)

C. mimula (Collin, 1949)

C. zetterstedti (Andersson, 1966)

Cryptonevra diadema (Meigen, 1830)

C. flavitarsis (Meigen, 1850)

C. tarsata (Fallén, 1820)

Dicraeus fennicus (Duda, 1933)

D. napaeus (Collin, 1947)

D. tibialis (Macquart, 1835)

Diplotoxa messoria (Fallen, 1820)

\begin{tabular}{|c|c|c|c|c|c|c|c|c|c|c|c|}
\hline & & & & & & 2 & & & 5 & & \\
\hline \multirow[t]{8}{*}{1} & 2 & & & & 4 & 1 & & & 3 & & \\
\hline & & & & & & & & 14 & 4 & & \\
\hline & 4 & & & & 2 & 1 & & & & & \\
\hline & & & & & & 1 & & & & & \\
\hline & 32 & 1 & & & 7 & & 6 & & 6 & 1 & \\
\hline & & & & & 1 & & & & & 1 & \\
\hline & & & & & & & 3 & 1 & 1 & & \\
\hline & 6 & & & & & & 2 & 2 & 5 & & 1 \\
\hline 3 & & 1 & & & 5 & 2 & & & 8 & 2 & 6 \\
\hline \multirow[t]{3}{*}{1} & & & & 1 & & & & & & 3 & \\
\hline & & & & 1 & & 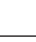 & & & & & \\
\hline & 1 & & & & & . & & & 5 & & \\
\hline \multirow[t]{2}{*}{7} & 3 & 1 & & 1 & 5 & 1 & & 2 & 24 & 1 & 2 \\
\hline & 4 & 1 & & & 3 & 2 & & & 2 & & 1 \\
\hline \multirow[t]{6}{*}{1} & 2 & 1 & & 1 & 6 & 8 & 12 & 24 & & & \\
\hline & 1 & & & & 2 & 1 & & & 2 & & \\
\hline & 4 & 1 & & & 6 & & 6 & & 11 & & \\
\hline & & 1 & & & & 7 & & & & 1 & 1 \\
\hline & 1 & 1 & & & 2 & & . & 2 & 3 & & \\
\hline & & & & & & & 2 & & & & \\
\hline \multirow[t]{19}{*}{4} & 8 & 2 & & 1 & 5 & 51 & 1 & 2 & & 25 & 3 \\
\hline & & & & & & & & & & & \\
\hline & & & & 1 & & & & 1 & & 2 & \\
\hline & & & & & 1 & & & & & & \\
\hline & & & & & & & & & & & \\
\hline & & & 1 & 1 & & & & & 4 & 1 & \\
\hline & & & 5 & 12 & & & 1 & 2 & 2 & 1 & \\
\hline & & 1 & & & & & & & & & \\
\hline & & & & & 1 & & & & & & \\
\hline & & 3 & & & & & & & & & \\
\hline & & & & & 1 & & & & & & \\
\hline & & & & & & & & 3 & & & \\
\hline & & & & 1 & 2 & 1 & & 4 & 1 & & \\
\hline & & & & & & 1 & & 2 & & & \\
\hline & & & & & 11 & 2 & & 1 & 5 & & \\
\hline & & & & & & & & & 1 & 2 & \\
\hline & & & & & & & & & 1 & 1 & \\
\hline & & & & & & 8 & 6 & & & 1 & \\
\hline & & & & & 1 & & & & & & \\
\hline 1 & & & & & 4 & 1 & & 94 & 55 & & \\
\hline 2 & & 3 & & 6 & 6 & 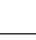 & & 3 & 1 & 29 & 15 \\
\hline 1 & & & & & 1 & 4 & 3 & 1 & & 5 & \\
\hline \multirow[t]{3}{*}{1} & & & 4 & 1 & 2 & 1 & 5 & 2 & 5 & 17 & 8 \\
\hline & & & & & & & 4 & & & & \\
\hline & & & & & & & 3 & 39 & 15 & & \\
\hline 1 & & & & & 2 & & & & & & \\
\hline 5 & & & & & 1 & & & & & & \\
\hline \multirow[t]{2}{*}{2} & & & & & & & & & & & \\
\hline & 21 & & & & 2 & & 23 & & 2 & & \\
\hline \multirow[t]{4}{*}{2} & 46 & 5 & 1 & 5 & 1 & 2 & 251 & 12 & 4 & & \\
\hline & 13 & 11 & & & 1 & & 19 & 2 & 2 & & \\
\hline & & & & 2 & 1 & & 1 & & & & \\
\hline & & & & & & & & & & 1 & \\
\hline \multirow[t]{2}{*}{1} & & & & & & & & & & & \\
\hline & & & & & & & 1 & 2 & & & \\
\hline
\end{tabular}


Elachiptera cornuta (Fallén, 1820)

E. diastema (Collin, 1946)

E. scrobiculata (Strobl, 1900)

E. tuberculifera (Corti, 1909)

Epichlorops puncticollis (Zetterstedt, 1848)

Eribolus hungaricus (Becker, 1910)

Hapleginella laevifrons (Loew, 1858)

Homalura tarsata (Meigen, 1826)

Incertella albipalpis (Meigen, 1830)

I. kerteszi (Becker, 1910)

I. zuecheri (Duda, 1933)

Lasiambia fycoperda (Becker, 1910)

L. palposa (Fallén, 1820)

Lasiosina albipila (Loew, 1866)

L. cinctipes (Meigen, 1830)

Lipara pullitarsis (Doskočil et Chvala, 1971)

Meromyza mosquensis (Fedoseeva, 1960)

M. nigriseta (Fedoseeva, 1960)

M. nigriventris (Macquart, 1835)

M. pluriseta (Pétčrfi, 1961)

M. pratorum (Meigen, 1830)

M. saltatrix (Linnaeus, 1761)

M. sororcula (Fedoseeva, 1962)

M. triangulina (Fedoseeva, 1960)

M. variegata (Meigen, 1830)

Microceris trigonella (Duda, 1933)

Ocsinella pusilla (Meigen, 1830)

O. frit (Linnaeus, 1761) s. 1.

O. maura (Fallén, 1820)

O. nitidissima (Meigen, 1838)

Oscinimorpha minutissima (Strobl, 1900)

Oscinisoma cognatum (Meigen,1830)

Platycephala planifrons (Fabricius, 1798)

P. umraculata (Fabricius, 1794)

Psudopachychaeta approximatonervis (Zetterstedt, 1838)

$P$. heleocharis (Nartchuk, 1964)

Rhopalopterum anthracinum (Meigen, 1830)

R. fasciola (Meigen, 1830)

R. platythorax (Nartshuk, 1958)

Speccafrons halophila (Duda, 1933)

Thaumatomyia glabra (Meigen, 1830)

T. hallandica (Andersson, 1966)

T. notata (Meigen, 1830)

T. trifasciata (Zetterstedt, 1848)

Trachysiphonella pygmaea (Meigen, 1838)

T. scutellata (von Roser, 1840)

Tricimba cincta (Meigen, 1830)

\section{Sepsidae}

Nemopoda nitidula (Fallén,1820)

Saltella sphondylii (Schrank, 1803)

Sepsis cynipsea (Linnaeus, 1758)

S. duplicata (Haliday, 1838)

S. flavimana (Meigen, 1826)

S. fulgens (Meigen, 1826)

S. neocynipsea (Melander et Spuler, 1917)

S. orthocnemis (Frey, 1908)

\begin{tabular}{|c|c|c|c|c|c|c|c|c|c|c|c|}
\hline & 1 & 1 & & & 2 & & & 1 & 5 & & 1 \\
\hline 1 & & & & & & 1 & & & 2 & & \\
\hline \multirow[t]{5}{*}{1} & & 1 & & & & 1 & & & & & \\
\hline & & 11 & & & 4 & & & & & 3 & 5 \\
\hline & & & & 2 & & & & & & & \\
\hline & 3 & & & & & & 2 & & & & \\
\hline & & 1 & & 1 & 2 & 1 & & & & 4 & 1 \\
\hline 1 & 1 & & & & & & 1 & & & & \\
\hline 1 & & 1 & & 181 & 8 & & 1 & & 1 & 1 & 1 \\
\hline \multirow[t]{4}{*}{32} & 1 & & & 2 & 8 & & 7 & 1 & 1 & & \\
\hline & & & & & 2 & & & & & & \\
\hline & & & & & & & 1 & & & & \\
\hline & & & & 2 & & & & & & & \\
\hline \multirow[t]{5}{*}{1} & 5 & & & 1 & 8 & & 19 & 4 & 1 & & \\
\hline & 1 & & & 2 & 1 & & 2 & 6 & 8 & 1 & 1 \\
\hline & & 1 & & & & & & & & & \\
\hline & & & & 14 & 2 & & . & 1 & 4 & 1 & \\
\hline & & & & 22 & 9 & & & & & & \\
\hline \multirow[t]{3}{*}{1} & 7 & & & 39 & 69 & & 3 & 13 & 6 & 1 & 1 \\
\hline & & & & & & & & 1 & & & \\
\hline & & & & 1 & & & & 7 & 8 & 1 & \\
\hline \multirow[t]{5}{*}{2} & & & & 1 & 1 & & & & & & \\
\hline & & & & & & & 3 & 76 & 93 & & \\
\hline & 1 & & & 9 & 13 & & & 25 & 9 & & \\
\hline & & & & & & & & 1 & 1 & & \\
\hline & & & & 5 & 17 & & 8 & 55 & 25 & 5 & \\
\hline 17 & 6 & 1 & 13 & 121 & 14 & & & 6 & 3 & 9 & \\
\hline \multirow[t]{3}{*}{13} & 132 & 2 & 95 & 367 & 166 & & 29 & 63 & 5 & 19 & 6 \\
\hline & & & & & 1 & & & & & 1 & \\
\hline & & 1 & & & 4 & & 3 & 9 & & 1 & \\
\hline \multirow[t]{7}{*}{5} & & 3 & 3 & 21 & 1 & 1 & 2 & 1 & & 2 & 4 \\
\hline & & & & & & 1 & & & & & \\
\hline & 29 & & & & 1 & & 14 & & 2 & & \\
\hline & 1 & & & 1 & & & & & & & \\
\hline & 7 & 15 & 12 & 6 & 1 & & & & 1 & & 3 \\
\hline & & 10 & & & & & & & & & \\
\hline & & & & & & & 1 & 1 & 2 & & 1 \\
\hline \multicolumn{12}{|l|}{1} \\
\hline \multicolumn{12}{|l|}{2} \\
\hline & 2 & & & & 2 & & & & 3 & & \\
\hline & & & & 1 & & & & 1 & 2 & & \\
\hline & 1 & 1 & & 2 & 1 & & & 5 & 7 & & 1 \\
\hline \multirow[t]{2}{*}{8} & 3 & & 1 & 7 & 33 & 1 & 4 & 12 & 28 & 2 & 5 \\
\hline & & & & & & & & 1 & 4 & & \\
\hline 62 & 3 & 54 & 1 & 8 & 13 & 4 & 14 & 15 & 1 & 12 & 2 \\
\hline 1 & 4 & 5 & & 2 & 4 & & 11 & 31 & 8 & 1 & \\
\hline \multirow[t]{4}{*}{6} & & 22 & 9 & 1 & 13 & & 2 & & 1 & 16 & 5 \\
\hline & & & & & & & & & & & \\
\hline & & & & & & 1 & & 1 & 1 & 2 & \\
\hline & & & & 3 & 2 & & & & & & \\
\hline \multirow[t]{3}{*}{66} & 3 & 43 & 14 & 9 & 38 & 1 & 1 & 11 & 52 & 6 & 26 \\
\hline & & & & 6 & 4 & & & 3 & 3 & 2 & \\
\hline & & & & & 2 & & & 12 & 6 & & 1 \\
\hline 231 & 8 & 14 & 1 & 6 & 14 & 1 & 2 & 55 & 16 & 7 & 20 \\
\hline \multicolumn{12}{|l|}{1} \\
\hline 8 & & 4 & 1 & 1 & 7 & 2 & & 26 & 5 & 1 & 1 \\
\hline
\end{tabular}

Proc. Latvian Acad. Sci., Section B, Vol. 68 (2014), No. 1/2. 
S. punctum (Fabricius, 1794)

Themira annulipes (Meigen, 1826)

T. gracilis (Zettersedt, 1847)

T. minor (Haliday, 1833)

T. putris (Linnaeus, 1758)

Xenosepsis fukuharai (Iwasa, 1984)

\section{Anthomyzidae}

Anthomyza bifasciata (Wood, 1911)

A. collini (Andersson, 1976)

A. dissors (Collin, 1944)

A. gracilis (Fallén, 1823)

Fungomyza albimana (Meigen, 1830)

Stiprosoma sabulosum (Haliday, 1837)

Typhamyza bifasciata (Wood, 1911)

\section{Asteiidae}

Asteia concinna (Meigen, 1830)

\section{Milichiidae}

Phyllomyza securicornis (Fallén, 1823)

\section{Heleomyzidae}

Suillia atricornis (Meigen, 1830)

S. bicolor (Zetterstedt, 1838)

S. flava (Meigen, 1830)

S. fuscicornis (Zetterstedt, 1847)

S. laevifrons (Loew, 1862)

Trixoscelis canescens (Loew, 1865)

T. obscurella (Fallén, 1823)

\section{Diastatidae}

Diastata fuscula (Fallén, 1820)

D. nebulosa (Fallén, 1823)

Drosophilidae

Drosophila bifasciata (Pomoni, 1940)

D. cameraria (Haliday, 1833)

D. fenestrarum (Fallén, 1823)

D. histrio (Meigen, 1830)

D. melanogaster (Meigen, 1830)

D. phalerata (Meigen, 1830)

D. rufifrons (Loew, 1873)

D. transversa (Fallén, 1823)

Leucophenga maculata (Dufour, 1839)

Scaptomyza flava (Fallén, 1823)

S. graminum (Fallén, 1823)

S. griseola (Zetterstedt, 1847)

S. pallida (Zetterstedt, 1847)

\section{Ephydridae}

Axysta cesta (Haliday, 1833)

Coenia curvicauda (Meigen, 1830)

C. palustris (Fallén, 1823)

Discocerina obscurella (Fallén, 1813)

Discomyza incurva (Fallén, 1823)

Hecomede albicans (Meigen, 1830)

Hyadina guttata (Fallén, 1813)

H. humeralis Becker, 1896

H. rufipes (Meigen, 1830)

H. scutellata (Haliday, 1839)

Hydrellia albilabris (Meigen, 1830)

\begin{tabular}{|c|c|c|c|c|c|c|c|c|c|c|c|}
\hline 5 & & 5 & & 2 & 13 & & 1 & 36 & 42 & 2 & 1 \\
\hline & & & & 11 & 15 & & & 4 & 1 & 2 & 4 \\
\hline & & & & & 1 & & & & & & \\
\hline & & & & 2 & & & & & & & \\
\hline & & & & 1 & & & & 1 & 3 & 1 & \\
\hline & & & & 1 & & & & & & & \\
\hline & & & & & 1 & & & & & & \\
\hline \multirow[t]{2}{*}{27} & 46 & 23 & 1 & 57 & 101 & 1 & 85 & 97 & 16 & 15 & 3 \\
\hline & & & & 1 & 1 & & & & & & \\
\hline \multirow[t]{5}{*}{4} & 5 & 2 & 2 & 108 & 191 & 6 & 5 & 54 & 6 & 1 & 1 \\
\hline & & 3 & 2 & & & & & & & 5 & \\
\hline & & & & & 1 & & & & & & \\
\hline & & & & & 1 & & & & & & \\
\hline & & & 1 & 84 & 55 & & & 3 & 1 & 3 & 2 \\
\hline \multirow[t]{2}{*}{2} & & 1 & & 5 & & 1 & & & & 1 & 1 \\
\hline & & & & & & 1 & & & & & \\
\hline 1 & & 15 & & 1 & & 9 & & & & 5 & 5 \\
\hline \multirow[t]{2}{*}{1} & 1 & 4 & 1 & 1 & & 9 & & & & 1 & \\
\hline & & 2 & & & & 1 & & & & & \\
\hline \multirow[t]{3}{*}{1} & & 2 & & & 1 & & & & & 1 & \\
\hline & & & 3 & & & & & & & 1 & \\
\hline & & & & 3 & & & & & & 1 & \\
\hline \multirow[t]{6}{*}{3} & & 2 & & & 1 & 4 & & & & & 1 \\
\hline & & & & & 1 & & & & 2 & & \\
\hline & & & & & & & & & & 1 & \\
\hline & & 2 & & 1 & & & & & & & 4 \\
\hline & & & & & & & & & & 1 & \\
\hline & & 1 & & & & & & & & & \\
\hline \multirow[t]{3}{*}{4} & & & & & & & & & & 1 & \\
\hline & & 1 & 1 & & & 3 & & & & & \\
\hline & & & 1 & & & & & & & 1 & \\
\hline \multirow[t]{4}{*}{3} & 1 & 2 & 9 & 1 & & 5 & 1 & & & 29 & 3 \\
\hline & & & & & 5 & & & & & & \\
\hline & & 32 & 1 & 2 & & & & & & 15 & 4 \\
\hline & & 17 & 12 & 6 & 36 & 2 & & 1 & 3 & 23 & 4 \\
\hline 11 & & 35 & 4 & 11 & 35 & & & 12 & 6 & 123 & 72 \\
\hline \multirow[t]{5}{*}{13} & & 293 & 24 & 88 & 921 & 20 & 1 & 12 & 14 & 1179 & 264 \\
\hline & & & & & 8 & & & 1 & & 4 & \\
\hline & & 1 & & 3 & 1 & & & & 6 & 3 & 6 \\
\hline & 1 & & & 1 & 3 & & & & 1 & & \\
\hline & & 1 & & 19 & 3 & & & 4 & & 5 & \\
\hline \multirow[t]{2}{*}{2} & & & & 1 & & & & 1 & & & 1 \\
\hline & & & & 1 & & & & & & & \\
\hline \multirow[t]{5}{*}{1} & 1 & & 12 & 16 & 1 & & 1 & 1 & 1 & 3 & 4 \\
\hline & & & & & & & & & 1 & & \\
\hline & & & & 8 & 1 & & 1 & & 5 & 3 & 1 \\
\hline & & & & & 3 & & 8 & & & & \\
\hline & & & & 1 & & & & & 1 & 6 & 1 \\
\hline
\end{tabular}


H. griseola (Fallén, 1813)

H. maculiventris Becker, 1896

Lamproscatella sibilans (Haliday, 1833)

Limnellia stenhammari (Zetterstedt, 1846)

Lytogaster abdominalis (Stenhammar, 1844)

Noctima picta (Fallén, 1813)

Notiphila aquatica (Becker, 1896)

N. caudata (Fallén, 1813)

N. cinerea (Fallén, 1813)

N. maculata (Stenhammar, 1844)

N. riparia (Meigen, 1830)

N. uliginosa (Haliday, 1839)

$N$. venusta (Loew, 1856)

Ochthera mantis (De Geer, 1776)

Paracoenia fumosa (Stenhammar, 1844)

Parydra cognata (Loew, 1860)

P. pusilla (Meigen, 1830)

Philygria flavipes (Fallén, 1823)

P. maculipennis (Robineu-Desvoidy, 1830)

P. nigricauda (Stenhammar, 1844)

P. punctatonervosa (Fallén, 1813)

Psilopa comta (Meigen, 1830)

P. leucostoma (Meigen, 1830)

P. nigritella (Stenhammar, 1844)

P. nitidula (Fallén, 1813)

P. polita (Macquart, 1835)

Scatella paludum (Meigen, 1830)

S. silacea (Loew, 1860)

S. stagnalis (Fallén, 1813)

S. subguttata (Meigen, 1830)

Trimerina madizans (Fallén, 1813)

\section{Scathophagidae}

Chaetosa punctipes (Meigen, 1826)

Cordilura ciliata (Meigen, 1826)

C. pudica (Meigen, 1826)

C. rufimana (Meigen, 1826)

Parallelomma albipes (Fallén, 1819)

Phrosia albilabris (Fabricius, 1794)

Scathophaga furcata (Say, 1823)

S. inquinata (Meigen, 1826)

S. stercoraria (Linnaeus, 1758)

S. suillia (Fabricius, 1794)

Spaziphora hydromyzina (Fallén, 1819)

\section{Muscidae}

Neomyia cornicina (Fabricius, 1781)

Schoenemyza litorella (Fallén, 1823)

\section{Calliphoridae}

Cynomya mortuorum (Linnaeus, 1761)

Lucilia illustris (Meigen, 1826)

L. silvarum (Meigen, 1826)

Melinda gentilis (Robineau-Desvoidy, 1830)

Pollenia labialis (Robineau-Desvoidy, 1830)

P. rudis (Fabricius, 1794)

P. varia (Meigen, 1826)

\section{Sarcophagidae}

\begin{tabular}{|c|c|c|c|c|c|c|c|c|c|c|c|}
\hline & & & & & & & & 2 & & & \\
\hline \multirow[t]{4}{*}{6} & 111 & 11 & 16 & 73 & 159 & & 12 & 225 & 76 & 61 & 43 \\
\hline & & & & 5 & 2 & & & & 2 & & \\
\hline & & 1 & 3 & 2 & 1 & & & & & & 1 \\
\hline & & & & & & 1 & & & & & \\
\hline \multirow[t]{3}{*}{4} & 3 & 2 & 3 & 25 & 18 & & 1 & 4 & 4 & 6 & 1 \\
\hline & & & & 2 & 23 & & 1 & & 39 & & 1 \\
\hline & & & & & 1 & & & & 3 & & \\
\hline \multirow[t]{8}{*}{2} & & & & & 4 & & & & 9 & & \\
\hline & & & & & & & & & 7 & & \\
\hline & & & & & & & & & 3 & & \\
\hline & & & & & & & & & 8 & & \\
\hline & & & & & & & & & 1 & & \\
\hline & 2 & & & & & & & & 2 & & \\
\hline & & & & & 1 & & & & & 2 & \\
\hline & & 1 & & & & & & 1 & 1 & & 2 \\
\hline \multirow[t]{3}{*}{1} & & & 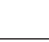 & & 6 & & & 1 & 1 & 2 & \\
\hline & & & & & 1 & & & & & & \\
\hline & 1 & & 1 & & 2 & & & & & 1 & \\
\hline \multirow[t]{5}{*}{4} & & & 3 & 28 & 3 & & & & 1 & 2 & \\
\hline & & & & 1 & & & & & & 1 & \\
\hline & & & & 1 & 2 & & & & 3 & & \\
\hline & & & & & 1 & & & & & & \\
\hline & 2 & & & & 1 & & 1 & & 2 & & \\
\hline 5 & 2 & & 9 & 18 & 33 & & 3 & 10 & 7 & 2 & 1 \\
\hline \multirow[t]{3}{*}{2} & & 2 & 1 & 30 & 41 & & & 11 & 5 & 2 & 1 \\
\hline & & & & 33 & 1 & & & 1 & 5 & & \\
\hline & & & & 1 & 1 & & & 1 & & & \\
\hline \multirow[t]{3}{*}{2} & 26 & 12 & 17 & 55 & 47 & & 1 & 123 & 411 & 11 & 21 \\
\hline & & & & 4 & & & & & & & \\
\hline & & & & & & 1 & & & & & \\
\hline 1 & 15 & & & 1 & 8 & & & 11 & 12 & 3 & \\
\hline \multicolumn{12}{|c|}{$1 x$} \\
\hline & & & & & & & & & 1 & & \\
\hline & & & & & & & & 5 & 16 & & \\
\hline \multirow[t]{5}{*}{2} & & & & & & & & & & & \\
\hline & & & & & & & & 1 & & & \\
\hline & & & & & & & & 1 & & & \\
\hline & & & & & & & & 2 & & & \\
\hline & & 5 & & 1 & & 3 & & 6 & 2 & 1 & 1 \\
\hline \multirow[t]{4}{*}{2} & 2 & 13 & & & 2 & 4 & & 14 & 13 & 4 & 1 \\
\hline & & & & & 2 & & & & & & \\
\hline & & & & & & & & & & & \\
\hline & & & & & & & & 9 & & & \\
\hline \multirow[t]{7}{*}{1} & 22 & & 22 & 163 & 9 & & 1 & 68 & 58 & 7 & 2 \\
\hline & & & & & & & & & & & \\
\hline & & & & & & & & & 1 & & \\
\hline & & & & & 2 & & & & 1 & & \\
\hline & & & & & 2 & & & & & & \\
\hline & & & & & & 1 & & 1 & & & \\
\hline & & & & & 1 & 1 & & & & & \\
\hline 1 & & 1 & & & 1 & & 3 & 5 & 1 & & \\
\hline 1 & & & & & & & & 1 & & & \\
\hline & & & & & & & & & & & \\
\hline
\end{tabular}




\begin{tabular}{|c|c|c|c|c|c|c|c|c|c|c|c|c|}
\hline Sarcophaga carnaria (Linnaeus, 1758) & 1 & & & & 1 & & & & 1 & 2 & & \\
\hline S. lehmanni auct. nec. (Müller, 1922) & & & & & & & & & 1 & & & \\
\hline S. sinuata (Meigen, 1826) & & & & & & & & & & & 1 & \\
\hline$\underline{\text { S. similis (Meade, 1876) }}$ & 1 & & & & & & & & & & & \\
\hline \multicolumn{13}{|l|}{ Tachinidae } \\
\hline Tachina fera (Linnaeus, 1761) & & & & & & 1 & & & & & & \\
\hline T. grossa (Linnaeus, 1758$)$ & & & & & 6 & 6 & & & & & & \\
\hline Species richness & 103 & 78 & 106 & 57 & 129 & 175 & 101 & 86 & 142 & 151 & 126 & 94 \\
\hline Abundance & 1191 & 814 & 2622 & 514 & 1694 & 3304 & 805 & 985 & 2182 & 1884 & 2099 & 2048 \\
\hline
\end{tabular}

* Sample plot designations see in Table 1 